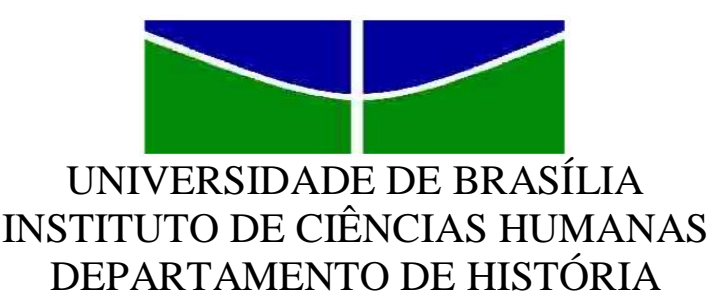

Vivência religiosa feminina no Brasil colonial

DAYANE AUGUSTA SANTOS DA SILVA

Brasília

2009 


\section{Vivência religiosa feminina no Brasil colonial}

Trabalho apresentado como requisito parcial para obtenção do título de bacharel em História do Departamento de História, Instituto de Ciências Humanas, Universidade de Brasília.

Orientador (a): Prof. $^{\text {a }}$ Dra. Teresa Cristina de Novaes Marques.

Prof. ${ }^{a}$ Dra. Teresa Cristina de Novaes Marques

(Orientadora)

Prof. ${ }^{a}$ Dra. Maria Therezinha Ferraz Negrão de Mello

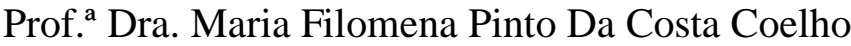

Prof. $^{\circ}$ Dr. Tiago Luís Gil

(Suplente) 
Fabricador de instrumentos de trabalho, de habitações, cultura e sociedades, o homem é também agente transformador da História. Mas, qual será o lugar do homem na História e o da História na vida do homem?

Autor desconhecido 
Para minha mãe Eulina, tão lutadora e amorosa, à memória do meu pai Renato, pela força e amor à vida e à Luciana, amiga, mãe e irmã. 


\section{AGRADECIMENTOS}

As exigências de elaboração de uma monografia resultam em muitos momentos de alegria, compreensão, prazer e realização, mas também de sentimentos indesejados, que, mesmo contra a minha vontade, trouxeram confusão, desânimo, fraqueza, dor e tristeza, materializada no choro. Encontrar o equilíbrio entre essas sensações foi um desafio que me proporcionou indescritível vontade de mudança. A vida muitas vezes me impôs barreiras difíceis de serem transpostas, no entanto, o desejo de me transformar trouxe uma incontrolável força para continuar, e, junto com ela, perseverar sempre!

Agradeço à UnB pelo despertar, à Diretoria de Desenvolvimento Social (DDS) que me proporcionou benefícios como à bolsa permanência, a alimentação estudantil e a moradia universitária, ao CNPq pela oportunidade de conclusão de dois PIC'S, ao Decanato de Extensão (DEX), pelo ensejo no projeto de extensão por dois anos consecutivos, ao programa Afroatitude Brasil, pelo desenvolvimento pessoal e financiamento da pesquisa, à Assessoria Internacional, pelo intercâmbio de idéias e oportunidade de bolsa de estudos na Universidade do Porto.

Agradeço aos meus pais Eulina Santos e Renato Augusto Moutinho da Silva, por me darem o principal: a vida e o amor. Devo a eles a força que tenho para enfrentar as dificuldades que surgem a cada momento. À querida Luciana, tão amorosa e dedicada, pelo incentivo e compreensão, tão necessários ao meu equilíbrio emocional. Ao amoroso Júnior, sempre disposto a me ouvir e conversar. Com ele aprendi que os textos de História estão sempre em silêncio para quem não lhes faz perguntas. À querida Luzinete, Suely e João Limeira, tão importantes com seus conselhos e pedidos de juízo.

À professora $\operatorname{Dr}^{\mathrm{a}}$ Teresa Cristina de Novaes Marques, mais que orientadora, amiga, devo, além da orientação e do olhar crítico e compreensivo, o estímulo, a confiança e o apoio para com os trabalhos que nasceram e se desenvolveram ao longo de quatro anos de convivência.

À professora Dr ${ }^{\mathrm{a}}$ Nancy Alessio Magalhães e bolsista de Extensão Edymara Dinis, agradeço os momentos partilhados e a constante manifestação de entusiasmo para com o projeto de extensão "Abrigos da Memória na Região de Brasília".

Às minhas queridas amigas e irmãs Sueny, Kênia, Katiúscia, Alenne e Anna Cristina, pequenos pedaços de mim. Pessoas com as quais partilhei alegrias e angústias, momentos de racional sanidade e deliciosas loucuras, mas, sobretudo, com as quais mantenho laços fortes de união, respeito, admiração, amor e amizade. Ao Marcos, meu 
querido e eterno irmão, agradeço a revisão deste trabalho, a amizade, o amor, respeito e loucuras intrínsecas.

Ao queridíssimo Lucas, pelo olhar cuidadoso e terno de cada dia, cada momento único e desigual dos demais. Pelo amor, dedicação e companheirismo. Nossa comunhão espiritual eu guardo no coração e levo comigo por eras sem fim. Sempre em frente!

Ao amado João, com quem partilhei momentos importantes da vida, com um simples olhar, um sonhar, um pensar, sem maiores expectativas, com total desapego. Com ele aprendi a conversar com as árvores, enxergar o céu, o sol e a lua e torná-los parte de mim.

$\mathrm{Na}$ graduação encontrei ajuda em momentos cruciais. Por parte de Soraia, Reinaldo, Welber, Juanita, Mayra, Priscila, Sulayne, Marco Antônio, Fumiko, Lélia, Rafinha, Josie, Alessandra Lima, colegas de contato quase diário. Fizeram-me entender certas solidariedades sobre as quais, até então, só havia ouvido dizer. Encontramo-nos na diferença. Agradeço a todos e todas, reconhecidamente.

Aos amigos Gabi, Ricardo, Suianni, Fernando e Guilherme Passamani, camaradas de outros momentos, mas sempre presentes na minha memória.

À Mariana, Lauana, Cássia e Rafaela, amigas da casa do estudante. Companheiras de todas as horas, pacientes, sinceras, meigas e, sobretudo, amorosas.

Aos queridos e novos amigos Bobson, Brunos Reis, Kenia, Camila Paula, Aracy Rosa, Guilherme Moura, Bruno Polengo e Taco

À Sinnara, Yamira e Paloma, amigas que me impulsionam a seguir em frente; a querida Carol, com quem dividi angústias e alegrias, para que meu equilíbrio fosse mantido; ao Antônio, cuja generosidade não hei de esquecer; ao Rafael Gomes, pelo partilhar de belos momentos; à Beatriz Amaral, dócil, dedicada e companheira; à minha irmã Jackeline e seu marido Valdeci Júnior; aos meus sobrinhos Yasmin, Henrique, Milena, Isabelle e Vinícius; a Goretti, ao Pedro Ramon, ao Diogo, ao Marco Aurélio, ao Beto, ao Luciano, ao Rauf, a Mary, a Nancy, ao Pedro, ao Lorran, a Gardênia, ao Helder, ao Derivaldo, amigas e amigos, enfim, a todos aqueles que de maneira direta ou indireta me deram sustentação para eu pudesse continuar meu caminho e me dedicar à UnB.

Obrigada a todos e todas! 


\section{SUMÁRIO}

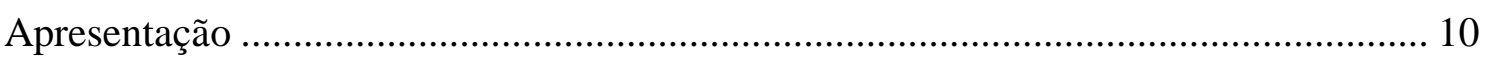

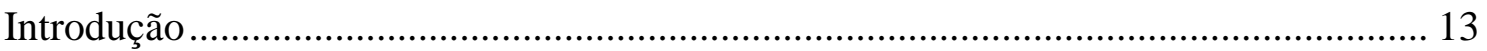

Capítulo 1. As Reformas do Catolicismo - um balanço historiográfico ........................ 18

Capítulo 2. Vivências religiosas femininas: As diversas faces de uma experiência ...... 30

Capítulo 3. Sagrado e Profano: Um olhar sobre a colônia ........................................... 40

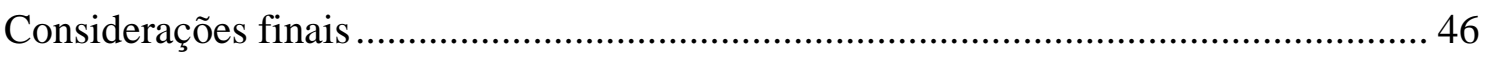

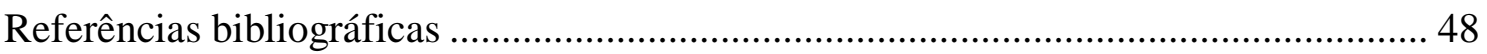




\section{RESUMO}

O presente trabalho resulta da análise de obras clássicas e recentes da historiografia brasileira e portuguesa sobre o catolicismo reformado e o seu impacto na experiência religiosa de mulheres moradoras nos domínios lusos. Investiga-se como as manifestações devocionais se configuravam sob a perspectiva de que o catolicismo tridentino (no modo como as reformas foram implementadas na América lusa) buscou estabelecer normas para o comportamento feminino. Trata-se de um estudo que permite uma análise mais ampla da reclusão feminina no período colonial, sem perder de vista a onda de mudanças que marcou a cristandade ocidental no período moderno - como o ímpeto reformador que se afirmou no Concílio de Trento e a interiorização da consciência moral baseada na culpa do pecado e sustentada por representações misóginas do feminino.

Palavras-chave: Contra-Reforma. Religiosidade. Experiência feminina. América portuguesa. Cultura popular. 


\begin{abstract}
This research results from the analysis of classic and recent works upon Brazilian and Portuguese historiography based on reformed Catholicism and its impact on the religious experience of women living in Portuguese areas. This article shows how the manifestations of devotion has shaped the perspective of the Tridentine Catholicism (in the way reforms were implemented in Portuguese America) established standards for female behavior. This is a study that allows a broader analysis of women's reclusion in the colonial period, without losing the wave of change that marked Western Christianity in the modern period - as the reform momentum held in the Council of Trent and the internalization of conscience based on the guilt of sin and supported by misogynistic representations of women.
\end{abstract}

Keywords: Counter-Reformation. Religiosity. Female experience. Portuguese America. Popular culture. 


\section{Apresentação}

$\mathrm{O}$ interesse pelo estudo da religiosidade feminina na sociedade colonial vem marcando minha formação em História. No ano de 2006, sob coordenação da $\operatorname{Prof}^{\mathrm{a}} \operatorname{Dr}^{\mathrm{a}}$ Teresa Cristina de Novaes Marques, concluí o PIC/CNPq com a temática de gênero e religiosidade no Brasil colonial. Neste projeto, realizei um estudo teórico sobre a experiência de mulheres negras na sociedade colonial. Examinei as representações contidas na historiografia sobre as mulheres negras acusadas de feitiçaria a partir das abordagens de Laura de Mello e Souza e de Luís Mott, porque são autores que reconstituem o universo simbólico e as práticas religiosas cotidianas das excluídas da história.

Busquei considerar as práticas mágicos religiosas que ocorriam no Brasil como um caso típico de "disjunção cultural, antes de ser sincretismo". ${ }^{1} \mathrm{O}$ universo mágico colonial foi, sem dúvida, sincrético para a maioria das feiticeiras e feiticeiros que dele participavam. No entanto, essas práticas foram variáveis e ressignificadas conforme as diferentes interpretações historiográficas deste período, que redescobriram uma religiosidade múltipla e heterogênea. Foi no confronto com a diversidade de olhares e sensibilidades dos historiadores da religião que me refugiei em noções como hibridismo $^{2}$ e circularidade cultural. ${ }^{3}$

O estudo teórico sobre as manifestações religiosas de populações escravizadas no Novo Mundo despertou um particular interesse no que diz respeito às práticas mágicos religiosas que ocorriam no Brasil colonial. O aprofundamento da leitura de obras específicas me permitiu perceber que as visitações do Santo Ofício, na forma como estão publicadas, não esgotou o universo das práticas culturais.

Determinei-me, desde o início, a centralizar minhas observações em torno de um ponto específico das práticas religiosas que ocorriam na sociedade colonial, considerando inexeqüível um trabalho de maior profundidade que abrangesse por completo a religiosidade dos moradores da América portuguesa.

\footnotetext{
${ }^{1}$ VAINFAS, Ronaldo. Ambivalências e adesões. In. A heresia dos índios: catolicismo e rebeldia no Brasil colonial. São Paulo: Companhia das Letras, 1995.

${ }^{2}$ Nestor Canclini entende hibridismo como processos sócio culturais em que as estruturas ou práticas "discretas", que existiam de forma separada, se combinavam para gerar novas estruturas, objetos e práticas.

${ }^{3}$ É uma metodologia que se aproxima da análise de Ginzburg que percebeu na circularidade entre a cultura erudita e popular uma formação cultural que teve como resultado o caráter hibrido no interior desse conflito. GINZBURG, Carlo. O queijo e os vermes - O universo de um moleiro no século XVI. São Paulo, Companhia das Letras, 2006.
} 
Procurar focalizar as congruências e os afastamentos metodológicos de dois autores referenciais em estudos de casos documentados por fontes inquisitoriais e eclesiásticas, sobre a mulher negra e a religiosidade popular foi certamente o que norteou o meu objeto de estudo, dado o paralelo metodológico de autores referenciais neste assunto e a metodologia de análise pelo viés de tradição intelectual e doutrinária da Igreja católica.

A escolha dos séculos XVI e XVII como período de estudo do presente trabalho foi devido à influência da historiadora Laura de Mello e Souza que, em O Diabo e a Terra de Santa Cruz, considera essa época como uma das mais interessantes para se entender a religiosidade da colônia portuguesa, onde as práticas religiosas se afastavam da doutrina católica e emergiam manifestações católicas sincréticas, fruto do contato cultural entre as etnias presentes naqueles espaço social. Comenta a autora: "Por um lado, a feitiçaria colonial mostrava-se estreitamente ligada às necessidades iminentes do dia-a-dia, buscando a resolução de problemas concretos. Por outro, aproximava-se muito da religião vivida pela população, as receitas mágicas assumindo com frequiência a forma de orações dirigidas a Deus, a Jesus, aos santos, à Virgem". 4

Começando por um primeiro ensaio relativo a tal período histórico, foi-me possível reunir informações e formular hipóteses que me fizeram repensar a vivência religiosa das mulheres, tendo em vista que a imagem da mulher no mundo português era carregada de estigmas negativos, que se somavam àqueles que recaíam sobre as mulheres de origem africana.

Levada por uma espécie de inconformidade pelo desconhecimento de registros de historiadores portugueses sobre o assunto em questão, concentrei em sua procura grande parte dos meus esforços no propósito de ampliar os meus horizontes de investigação. Em 2007, fui selecionada no âmbito do Programa de Bolsas LusoBrasileiras Santander Universidades, quando tive oportunidade de estender e aprofundar meus conhecimentos a partir da leitura de obras específicas como a dos historiadores José Pedro Paiva e Marcelo Bithencourt.

$\mathrm{O}$ intercâmbio acadêmico junto à Universidade do Porto e o contato com professores que estudam a religiosidade lusitana e seus domínios foi a oportunidade que tive de compreender como os historiadores portugueses têm visto as crenças e as superstições populares na colônia. José Pedro Paiva é enfático ao comentar que o sabat

\footnotetext{
${ }^{4}$ SOUZA, Laura de Melo e. O Diabo e Terra de Santa Cruz. São Paulo: Companhia das Letras, 1986, p.
} 17. 
é um mito de criação erudita, divergindo da historiadora Laura de Mello e Souza. Segundo o autor, essa prática é uma fusão que se constitui inicialmente na introdução de elementos alheios à cultura popular e estruturado principalmente pelas elites que ao tomarem contato mais profundo com certas crenças populares e ao tentarem integrá-la nos seus esquemas de inteligibilidade do universo, traduzindo-as, foram os responsáveis pela eclosão de uma nova idéia. ${ }^{5}$

O contato com os pesquisadores de origem portuguesa me propiciou uma visão mais ampla sobre a religiosidade popular na América portuguesa. Desta feita, pude articular com maior maturidade intelectual, proporcionada, inclusive pelo projeto de pesquisa inicial, as reflexões teóricas sobre a religião, particularmente direcionadas para o contexto ibérico.

Neste sentido, a realização de um segundo PIC/CNPq se articulou com o projeto-guia no propósito de ampliar a compreensão sobre a sociedade dos domínios lusos da América, ao tomar a dimensão religiosa como fundamento da constituição de identidades em uma sociedade de fortes expressões culturais.

No intuito de aprofundar os temas da minha pesquisa, busquei examinar a historiografia brasileira e portuguesa recente sobre a experiência religiosa feminina, após as reformas religiosas do Concílio de Trento. Para isso, me aprofundei na leitura de questões teóricas e metodológicas do campo da história social, nas leituras das transformações do catolicismo pós Trento, com ênfase na historiografia sobre a Igreja Ibérica e por último examinei a historiografia sobre a religiosidade feminina do espaço luso-brasileiro.

Este trabalho é, antes de tudo, a apresentação e análise historiográfica dos trabalhos expostos acima, o que exigiu paciente elaboração e cuidado no exame dos textos.

\footnotetext{
${ }^{5}$ PAIVA, José Pedro. Bruxaria e Superstição num país sem caça às bruxas. Lisboa: Notícias editorial,
} 1997. p. 157 


\section{Introdução}

Este estudo busca examinar a vivência religiosa de mulheres moradoras dos domínios lusos na América, nos séculos XVI e XVIII. Investiga-se, a partir de obras historiográficas brasileiras e portuguesas recentes, de que modo as mulheres elaboraram estratégias informais para viver a sua fé, mesmo sob maior controle da Igreja. Examinam-se trabalhos que discutem as relações existentes entre o sagrado e o profano, e, particularmente, entre magia e religião.

Também são abordadas as relações entre a feitiçaria e a ação repressiva da Igreja tridentina, que considerou heresias o que hoje entendemos como manifestações da religiosidade popular. A escolha do período deveu-se ao particular interesse de compreender como essas mulheres agenciaram suas escolhas religiosas em um ambiente que se constituiu de identidades diferenciadas, permeado por uma estrutura hierárquica, considerada desigual, como as estabelecidas no processo colonizador, entre metrópole, colonos, mulheres, índios e negros. Trata-se de um período que permite examinar as modificações de costumes e de mentalidades baseadas na fé católica reformada.

Em termos metodológicos, o estudo se inscreve nos domínios da história social, do cotidiano e da vida privada. O termo cotidiano será significado aqui como o concebeu Mary Del Priore ao explicar a vida cotidiana como um espaço que remete à vida privada e familiar e às atividades ligadas à manutenção dos laços sociais ${ }^{6}$. É no movimento das transformações sociais do cotidiano que percebemos determinada autonomia, porém ambígua, de uma vida privada e familiar, distinta da aparente vida pública que assume novas significações, um sentido moderno que passa, portanto, por uma invenção do cotidiano ${ }^{7}$.

Na perspectiva da história social, serão abordadas trajetórias individuais a fim de desvelar práticas sociais que só são percebidas quando determinado tipo de documentação é examinado, como as visitações do Santo Ofício, ou mesmo determinados elementos de âmbito popular onde transparecem produções da vida cotidiana, das relações familiares, entre outros. Aqui, conforme comenta Hebe de Casto,

\footnotetext{
${ }^{6}$ PRIORI, Mary del. Introdução. In. Ao sul do corpo: condição feminina, maternidades e mentalidades no Brasil Colônia. Rio de Janeiro: José Olympio; Brasília: Edunb, 1993.

${ }^{7}$ CERTEAU, M. de. A Invenção do Cotidiano. Petrópolis: Vozes, 1996.
} 
a história social é encarada como uma perspectiva de síntese, onde os níveis de abordagem do cotidiano estão inscritos no social e por isso se interligam. ${ }^{8}$

Buscamos observar ainda, a partir destes vieses metodológicos, práticas e hábitos que caracterizam o dia-a-dia da vivência religiosa de mulheres, que muitas vezes se enclausuraram em suas próprias residências, atribuindo a si próprias rituais de purificação. Para isso nos valemos da leitura de historiadores tais como: Laura de Mello e Souza, José Pedro Paiva, Luiz Mott, Rui A. Costa Barbosa, Delumeau, Leila Mezan, Maria Beatriz Nizza da Silva, Norbert Elias, entre outros. São pesquisadores que realizam uma leitura acurada das transformações doutrinarias do domínio luso, da Igreja Ibérica e da religiosidade feminina no espaço cultural luso-brasileiro.

No sentido mais amplo, este estudo busca compreender o universo religiosomágico colonial da América portuguesa a partir das correntes historiográficas que vem se reinterpretando o imaginário dos homens, de mulheres, de inquisidores e de feiticeiras durante os primeiros séculos da colonização. Trata-se de um exercício de contato com um universo cultural e simbólico peculiar à sociedade luso-brasileira nos trópicos.

Em trabalhos relevantes sobre a vida religiosa das mulheres na sociedade colonial, há referências especiais ao lugar da mulher no processo de montagem do projeto colonizador e de transformações sociais na América portuguesa.

Mary Del Priore, em Ao sul do corpo: condição feminina, maternidades e mentalidades no Brasil Colônia ${ }^{9}$, busca entender as trajetórias femininas a partir de documentos e fontes impressas entre os séculos XVI e XVIII. A autora buscou descobrir, por trás dos discursos normativos e eclesiásticos, o que a mulher deveria ser e como ela deveria se comportar. Comenta a autora que a conduta feminina descrita por estas instituições definia papéis sociais que costuravam as características do seu gênero, simbolicamente representadas pela maternidade, o corpo feminino e o cuidado com os filhos.

Leila Mezan considera a história da mulher como um campo bastante rico da história social. ${ }^{10}$ A autora acena para a vida de mulheres reclusas a fim de se

\footnotetext{
${ }^{8}$ CASTRO, Hebe. História Social. In. CARDOSO, Ciro F. S \& VAINFAS, Ronaldo (orgs). Domínios da História. Rio de Janeiro: Campus, 1997. ${ }^{9}$ PRIORI, Op. Cit.

${ }^{10}$ ALGRANTI, Leila Mezan. Introdução. In. Honradas e devotas: mulheres da Colônia: Condição feminina nos conventos e recolhimentos do Sudeste do Brasil, 1750 - 1822. Rio de Janeiro: José Olympio; Brasília: Edunb, 1993.
} 
compreender quem eram, como viviam e os motivos do enclausuramento daquelas que residiam nestes estabelecimentos, durante o século XVIII. Neles, as mulheres levavam uma vida de reclusão, sem fazerem votos perpétuos. É assim que a historiadora busca desvendar algumas facetas da condição feminina na América portuguesa. Trata-se, portanto, de considerar as formas de sociabilidade feminina que, longe dos muros destes recolhimentos, extrapolavam os limites dos espaços privados. ${ }^{11}$

Em O Diabo e a Terra de Santa Cruz, Laura de Mello e Souza ${ }^{12}$ elucida casos de feitiçaria desempenhada por mulheres que tinham a função de realizar práticas mágicas ora ofensivas, visando agredir, ora, defensivas, visando preservar, conservar a tensão permanente, constituinte da própria formação social do Brasil colonial. Muitas das feiticeiras usavam dos seus poderes para atrair clientes e conseguir dinheiro que lhes garantisse a sobrevivência. Parte da atribuição de poderes maléficos, por parte dos vizinhos e eclesiásticos, fornecia elementos necessários às perseguições inquisitoriais e visitações que se faziam nas capitanias.

Um balanço geral dessas e de outras contribuições bibliográficas aponta direções que buscam refletir sobre a vivência religiosa feminina no desenrolar histórico do Brasil e oferece subsídios historiográficos para que outras análises prossigam em caminhos de pesquisas, sugeridos pela reflexão das fontes primárias e revisões bibliográficas.

A documentação inquisitorial, os livros e textos avulsos e inseridos em obras diversas demonstram notável dispersão de informações em relação a este tema específico. Essa perspectiva nos permitiu confrontar a imagem da mulher santa e feiticeira, com a análise crítica do comportamento religioso e condição feminina da mulher.

Baseado nisso, buscamos entender num primeiro momento se existiu uma lógica mais racional e intensa com a forma do ser feminino pós Trento, para em seguida compreender de que maneira as idéias reformistas influenciaram o cotidiano feminino na colônia.

Para isso, organizamos este estudo em três capítulos. O primeiro capítulo, denominado "Reformas do Catolicismo - Um balanço historiográfico" procura localizar a religiosidade da colônia dentro dos quadros mentais existentes à época. Para tanto, buscamos entender como o contexto de Reforma Protestante se contrapôs ao

\footnotetext{
${ }^{11}$ Além de Mesan, a contribuição de Susan Soeiro persiste sendo uma referência nos estudos de instituições de enclausuramento feminino.

${ }^{12}$ SOUZA, Laura de Melo e. O Diabo e Terra de Santa Cruz. São Paulo: Companhia das Letras, 1986.
} 
catolicismo, trazendo idéias e condições modificadoras à época. O movimento reformador influenciou as novas formas de pensar e de sentir na dinâmica da época Moderna. Este processo que culminou no Concílio de Trento, com a Contra-Reforma, deu nova dinâmica à vida portuguesa e marcou mudanças que estimulou um movimento tridentino que queria impor, através de palavras e costumes civilizatórios, um catolicismo mais vigilante e de senso prático também na América portuguesa. Tratavase de uma modificação de costumes de vida e de mentalidade baseada na vivência de uma fé católica reformada.

O segundo capítulo, "Vivências religiosas femininas: as diversas faces de uma experiência" busca focalizar a vida das religiosas e desviantes na moralidade cristã e européia. Examinamos a forma como o cristianismo se impôs como a única e verdadeira doutrina religiosa, controlando a conduta de um grande número de fiéis, em especial das mulheres, consideradas na época mais traiçoeiras e maliciosas do que os homens. Neste capítulo, analisamos, com base na dicotomia entre mulheres feiticeiras e de recato, a construção do discurso moralista modernizador, nos espaços públicos e privados da colônia. Buscamos compreender o código moral da época que expressava conselhos e advertências sobre a conduta feminina e revelava o ideal de mulher na América portuguesa.

"Sagrado e Profano: Um olhar sobre a colônia" é o terceiro capítulo desde trabalho. Nele buscamos focalizar a inserção de uma religiosidade híbrida movida por um conjunto de práticas que veio a se denominar de profanas. Aqui o profano aproximase do impuro e domina o pólo negativo do mundo espiritual. Examinamos a historiografia que versa sobre as relações existentes entre o sagrado e o profano, e, particularmente, entre magia e religião.

Deixar emergir a memória de tensões entre os eclesiásticos, colonos, os homens e as mulheres é vislumbrar além de seus conflitos e complementaridades o tecido da narrativa histórica. Lidar com esta experiência é perceber a representação e o assombro do colonizador europeu com o "Outro".

Não se trata de um estudo exclusivo da história da Igreja, ou sobre a religiosidade popular. Neste trabalho, diretrizes e eventos importantes do desenvolvimento da Igreja Católica são fundamentais assim como a situação colonial e o recorte temático de gênero. São aspectos que abarcam a Igreja enquanto instituição, a realidade social da colônia, os papéis femininos e de sua sociabilidade. Busca-se, portanto, penetrar neste universo, sem perder de vista as diferenças e distâncias que 
compunham costumes, saberes e poderes próprios das moradoras da América portuguesa. 


\section{Capítulo 1. As Reformas do Catolicismo - um balanço historiográfico}

As pesquisas mais atualizadas sobre a Reforma protestante concordam em um importante aspecto interpretativo: não é possível sustentar a tese segundo a qual um único movimento, de tão significativas proporções, tenha resultado apenas da discordância de Lutero com os dogmas cristãos. Interpretações baseadas em argumentos desse gênero são simplificadoras. Os estudos mais recentes, sem deixar de considerar o importante papel dos reformadores nos eventos da época, inclinamse no sentido de entender as implicações próprias de um movimento religioso que ultrapassou as questões institucionais e eclesiásticas no século XVI. ${ }^{13}$

A historiografia nem sempre se atentou a essas relações e desdobramentos, no entanto, pode-se afirmar que os pesquisadores têm-se esforçado para procurar compreender melhor os aspectos culturais, sociais, de cotidiano e de poder vividos nos vários movimentos reformistas que foram surgindo ao longo do período já referido. Não sem razão, Ronaldo Vainfas nos esclarece [que] "a moderna historiografia prefere falar em Reformas, pois ambas as vertentes, protestante e católica, partilharam motivos comuns", expurgando as superstições heréticas ou demoníacas e extirpando o pecado. ${ }^{14}$ Tal foi a substância do impacto da Reforma e da Contra-Reforma nos domínios lusos, do que resultou um grande programa de evangelização de massas em todos os âmbitos da vida social e religiosa daquela gente.

Para medir o alcance da repercussão da Reforma na Europa, basta observar a cautela que a Igreja dispensa aos fiés no sentido de preservá-los das temidas idéias reformistas. Na época que antecedeu à Reforma, eram cada vez mais remotas as chances de reconciliar as angústias da cristandade católica por intermédio da Igreja. O apostolado Católico já não conseguia atender às necessidades espirituais, reverter o quadro de medo e de incerteza que tomava conta das consciências de seus fiéis.

A Reforma representou uma resposta válida aos anseios de uma época. Determinou uma nova duração do tempo e marcou a ruptura, ou mesmo uma

\footnotetext{
${ }^{13}$ DELUMEAU, Jean. História do medo no Ocidente. 1300 - 1800. São Paulo: Schwarcz, 1996. SOUZA, Laura de Melo e. Inferno Atlântico: Demonologia e colonização séculos XVI - XVIII. São Paulo: Companhia das Letras, 1993. MOTT, Luis. Rosa Egipcíaca - Uma santa africana no Brasil. Rio de Janeiro: Bertrand Russel, 1993. VAINFAS, Ronaldo. Trópico dos pecados: moral, sexualidade e inquisição no Brasil Colonial. Rio de Janeiro: Campus, 1989. AZZI, Riolando. Razão e Fé: o discurso da dominação colonial. São Paulo: Paulinas, 2001.

${ }^{14}$ VAINFAS, Ronaldo. A Contra-Reforma e o Além-Mar, In. Trópico dos Pecados: moral, sexualidade e inquisição no Brasil Colonial. Rio de Janeiro: Campus, 1999, p. 9.
} 
continuidade inovadora que seguiu em contraposição às invenções dos continuísmos tradicionais que a Igreja defendia. "A Reforma protestante é, portanto, a autoridade da Sagrada Escritura, a justificação pela fé e a consciência de uma renovação, é portanto, uma modificação na percepção da duração". ${ }^{15}$

A reforma anunciada encontrou na Europa condições viáveis para se tornar uma reforma humanista cujos modelos se baseiam numa releitura do novo testamento e dos Salmos, traduzidos em língua vulgar. Ela inspirou a busca por um lado mais "primitivo" da Igreja apostólica, da simplificação da liturgia.

Neste momento, a verdadeira justiça consistiu em amar o bem e cultivar a espiritualidade do amor desinteressado. Sobre isso, comenta Chaunu [que] "podemos encontrar, através do canal da piedade, uma ressurgência (no final do século XII e no século XVIII) do puro luteranismo evangélico, até às origens do imperativo categórico Kantiano - Não fazer o bem é não amar a Deus". ${ }^{16}$

A rápida propagação das idéias reformistas nos permite reconhecer os laços existentes entre as razões religiosas e extra-religiosas que estimularam a conversão de vários fiéis. As idéias dos reformadores representaram um marco na história do cristianismo. Pode-se perceber com maior clareza um antes e um depois na vida religiosa da civilização ocidental. Aqui a Reforma é sinônimo de ruptura; a Igreja, de continuidade.

O movimento reformador influenciou as novas formas de pensar e de sentir a dinâmica da época Moderna. Enquanto estudiosos laicos entendiam a Reforma como fundação do caminho para a liberdade, católicos ultramontanos, defensores da infabilidade papal, observavam-na como um equívoco que desestabilizou princípios de autoridade, de ordem social e de disciplina, característicos da cristandade medieval $^{17}$

Os reformadores advogaram práticas mais simples e mais evangélicas para a religião cristã. Despojada de dogmas misteriosos e de liturgias de difícil compreensão, a devoção moderna insistia em uma religião que desvalorizasse a hierarquia, a adoração aos santos e as cerimônias.

\footnotetext{
${ }^{15}$ CHAUNU, Pierre. Teoria Geral da Reforma Protestante. In. O Tempo das Reformas (1250-1550) II. A Reforma Protestante. Lisboa, edições 70, 1975, p. 158.

${ }^{16}$ Idem, p. 105.

${ }^{17}$ MARRAMAO, Giacomo. Céu e Terra. Genealogia da secularização. São Paulo: Editora Unesp, 1997, p. 26-30, primeira edição italiana de 1994. Apud MONTEIRO, Rodrigo Bentes. As Reformas Religiosas na Europa Moderna - notas para um debate historiográfico. In. Varia Historia, Belo Horizonte, vol. 23, $\mathrm{n}^{\mathrm{o}}$ 37: p. 130-150, Jan/Jun 2007. p. 131
} 
Luizetto comenta a importância do papel desempenhado pelos participantes da devoção moderna. ${ }^{18}$ Seguindo os ensinamentos que aprenderam no Evangelho, os praticantes dessa devoção cristã não adotavam a vida monástica, não tomavam votos, não valorizavam a contemplação mística e cerimoniais, em favor da prática da caridade, empenho no trabalho e divulgação da Bíblia. Por essa razão, os irmãos da "Vida Comum" contentavam-se com orações, meditações, leitura do Evangelho e ascese.

As vozes reformistas que demonstravam inquietação e insatisfação com os caminhos da vida religiosa clamavam por práticas e medidas que afirmassem os dogmas cristãos. A ameaça das idéias reformadoras suscitou um movimento de defesa e combate, em todos os aspectos da vida religiosa ocidental. "Nem certeza de salvação, nem desespero por não ser salvo, eis o estado de tensão, de equilíbrio instável, que o ensino eclesiástico cria e quer manter."19

As investidas doutrinárias passaram a tomar corpo com a impressão de textos e livros de devoção que professavam as verdades instituídas pela fé católica. Foi um momento em que a humanidade se confrontou com claras e definidas manifestações da Verdade. Já observou Peter Gay ao comentar [que] "mesmo o cristão mais moderado tem de considerar a sua religião como absolutamente verdadeira (todas as outras, portanto, como radicalmente falsas) e os pagãos como precursores involuntários, ou inimigos incorrigíveis, ou almas miseráveis não iluminadas". 20

A persistência de práticas pagãs preocupava os teólogos e isso pode ser notado nos movimentos de reforma da época: tanto na Reforma protestante, como na reação católica. Ambas buscavam compreender e repensar o cristianismo. Para além disso, diminuir as distâncias que separavam a religião vivida na prática pelos seus fiéis daquela pregada pelo clero e teólogos da Igreja. Essa preocupação vinha das correntes necessidades dos fiéis de encontrar respostas religiosas apropriadas às suas mazelas espirituais e disposição para se converter e/ou usar ritos das novas confissões.

\footnotetext{
${ }^{18}$ LUIZETTO, Flávio. A Contra-Reforma. In. Reformas Religiosas - Lutero e Calvino. A Contra Reforma e os jesuitas - A crise da modernidade. $3^{\mathrm{a}}$ ed. São Paulo: Contexto, 1994. p. 30-31

${ }^{19}$ CHAUNU, Pierre. Op. Cit. p. 78.

${ }^{20}$ GAY, Peter. The Enlightenment: The Rise of Modern Paganism, 2 vols., Nova Iorque: 1967, vol. 1. p. 170, Apud BOXER, C. R. Interaccões Culturais. In. A Igreja e a Expansão Ibérica (1440-1770). Lisboa: edições 70, 1978, p. 55.
} 
O movimento de Contra-Reforma se manifestou de inúmeras maneiras. Por todos os meios possíveis, buscou-se converter as populações que aderiam às "heresias", através das missões jesuítas e do estabelecimento da Inquisição. Os decretos tridentinos trataram de refutar os ideais protestantes e de reafirmar os fundamentos religiosos da Igreja católica. Flávio Luizetto comenta: "era preciso cuidar da elevação do nível cultural dos padres, da sua instrução geral e religiosa, para que pudessem bem administrar os sacramentos, compreender as confissões e as regras do ritual e das cerimônias religiosas". ${ }^{21}$

Num primeiro momento, a influência que essas novas idéias tiveram na vida portuguesa parece ter sido pequena, mas, quando nos voltamos mais atentamente para aspectos e acontecimentos marcados pelos movimentos de inspiração reformista, surpreendemo-nos. O historiador português Rui Costa Barbosa corrobora esta idéia ao analisar a adesão da sociedade portuguesa à Reforma. ${ }^{22}$ Segundo este autor, a constatação de uma inexistente adesão à Reforma no espaço português, não é de estranhar. Não pela recusa das populações em abandonarem ou mesmo repensarem suas crenças, mas sim pela emergente ação da Inquisição em Portugal, mais tarde confirmadas com as posições doutrinárias do Concílio de Trento. Completa Barbosa:

Até o século XIX, não aparecer a circular, em Portugal, quaisquer impressos protestantes, devido especialmente à apertada malha de vigilância inquisitorial que, permanentemente, remetia para o rol dos livros proibidos os textos suspeitos dessa proveniência e, de um modo sistemático, vasculhava tipografias, bibliotecas e arquivos particulares, além do controlo das cargas dos navios que escalavam os portos nacionais. Muitos dos casos de apreensão de livros suspeitos ou com doutrina luterana, mencionados nas actas inquisitorias, eram pertença de pessoas em trânsito na cidade de Lisboa, geralmente mercadores e mareantes flamengos, alemães ou ingleses e, em alguns casos, os seus hospedeiros também estrangeiros que, frequentemente, desempenhavam funções consulares e, cumulativamente, exploravam locais de alojamento. ${ }^{23}$

\footnotetext{
${ }^{21}$ LUIZETTO, Op. Cit. p. 64.

${ }^{22}$ OLIVEIRA, Rui A. Costa. Resquícios históricos da presença da Reforma no espaço lusófono durante o século XVI. In. Revista Lusófona de Ciência das Religiões - Ano, 2006/ nº 9/10 - 75 - 102.

${ }^{23}$ Idem, p. 78
} 
De mesma opinião, Bethencourt conclui que as pressões provocadas pelo movimento reformador em Portugal foram mais sutis que no restante da Europa ${ }^{24}$ Este abrandamento permitiu o uso de orações e imagens da Igreja Católica nas crenças de raízes populares, representadas com menor grau de importância em relação à doutrina protestante. ${ }^{25}$ As populações portuguesas adotavam práticas e tinham crenças que mantinham um conjunto de costumes reproduzidos secularmente por via oral, daí a forte circulação de culturas com raízes árabes, judias e européias.

Após Trento, a Igreja estava empenhada em eliminar os vestígios das idéias luteranas em Portugal, e, apesar disso, permaneciam indícios desses ideários em expressões populares do povo português. Rui Costa Barbosa comenta que o povo comum expressava-se através de frases do tipo "Cada um pode salvar-se na sua fé" ou mesmo "Nada há mais, que viver e morrer". Essas idéias poderiam expressar determinado compromisso ético e individual com uma outra crença religiosa e/ou ainda questionar o que se apresentava como única Verdade que salva. Era uma maneira de evitar possíveis confrontos com "situações de escolha que ditariam o abandono das suas tradições religiosas herdadas". ${ }^{26}$ Apesar disso, a suspeição ganhou terreno e acabou por influenciar as denúncias de desvios comportamentais.

Paiva assinala o esforço de evangelização, principalmente após Trento, voltado para as culturas populares. ${ }^{27}$ A Igreja passou a realizar missões, a se preocupar com os sermões, a colocar em práticas as visitas pastorais e estimular as confissões. Fez tudo isso num ritmo cada vez mais acelerado que visava atender às recomendações do Concílio de Trento. ${ }^{28}$ É dessa necessidade que surge a cooperação entre os poderes secular e regular para que a Igreja fosse bem dirigida e suas doutrinas e ensinamentos corretamente transmitidos. Escreve Luizetto: ${ }^{29}$

\footnotetext{
${ }^{24}$ BETHENCOURT, Francisco. "Campo religioso e Inquisição em Portugal no século XVI" In. AZEVEDO, Joaquim. (org). Estudos contemporâneos - religiosidade popular. Portugal: Porto, 1984. ${ }^{25}$ PIMENTEL, Helen Ulhôa. Cultura Mágico-Supersticiosa. In. Universo Mágico Colonial. Feiticeiros e inquisidores nos dois primeiros séculos da colonização do Brasil .Brasília: 2005, p. 36. Com adaptações. ${ }^{26}$ OLIVEIRA, Op. Cit. p. 80.

${ }^{27}$ José Pedro Paiva é autoridade para Portugal e referência em estudos sobre o universo mágico colonial. Paiva examina o imaginário, a existência e a repressão aos crimes de bruxaria, feitiçaria e encantamento em Portugal. PAIVA, José Pedro. Bruxaria e Superstição num país sem caça às bruxas - 1600-1774. Lisboa: Notícias, 1997.

${ }^{28}$ Ibidem, p. 37

${ }^{29}$ LUIZETTO, Flávio, Op. Cit. p. 65
} 
Somadas às medidas que tinham por objetivo revigorar a doutrina, essas providências relativas à renovação da vida clerical constituem um aspecto decisivo da reforma católica, com o que a Igreja romana visava consolidar antigas posições, deter o avanço do protestantismo e, se possível, reconquistar para a confissão católica pessoas e territórios convertidos ao credo protestante.

O caso de Damião de Góis é exemplar quanto a definiçãa das suas convicções religiosas. ${ }^{30}$ Ele é citado por alguns pesquisadores como um forte aderente à Reforma, pois, em suas declarações ao Tribunal do Santo Ofício, constam dúvidas acerca das indulgências e da necessidade de se confessar. Dois temas sensíveis às doutrinas da cristandade católica.

O impacto do movimento reformista não se mostrou tão incisivo na América portuguesa como foi na Europa ou mesmo em Portugal, mas determinou distintas mudanças num movimento tridentino que queria impor, através de palavras e costumes civilizatórios, um catolicismo mais vigilante e de senso prático. Tratavase de uma modificação de costumes de vida e de mentalidade baseada na vivência de uma fé católica reformada.

Nos domínios ultramarinos encontram-se o máximo de condições reunidas para a formação de uma sociedade dúbia, marcada por extremos - expressos nos binarismos da época, onde os espaços, quer fossem ideológicos, culturais ou religiosos, demarcavam limites nítidos e bem definidos. Isso dá origem a uma estrutura que favorece a religião tradicional, no entanto, abre margens a um tipo de pensamento religioso católico de recusa, antes mesmo do aparecimento da Reforma.

Estabelecia-se naquela época o domínio das descobertas, o cultivo de um sentimento religioso profundamente enraizado na chamada "natureza humana" e o culto da civilização ocidental; sociedade modelo e imutável, organizada por leis rígidas e imunes às transformações. Habitar este mundo era se defrontar com o que hoje chamaríamos de 'surrealismo inimaginável'. Aos olhos de Miguel Faria esse momento "revela a complexidade do espírito de uma época em que coexistem a par, nos mesmos agentes, a moderna vontade da mudança e os vínculos profundos com o passado. Ousar e acatar". ${ }^{31} \mathrm{O}$ medo sentido pela "civilização européia no início

\footnotetext{
${ }^{30}$ Segundo Rui A. Costa, Damião de Góis estabeleceu contato próximo com todos os reformadores da época, em diversas situações. Foi o que lhe valeu a acusação de ser portador de idéias reformistas e ser preso desde de 4 de abril de 1571 até 16 de dezembro de 1572.

${ }^{31}$ FARIA, Miguel. Vaticínios e superstições 1524 - 1577. In. Revista Oceanos, Ano, 1993/nº 13/50 - 57, p. 51
} 
dos tempos modernos e antes da descoberta do "inconsciente": ao "temor", ao "pavor", ao "terror" e ao sobressalto" revelou a complexidade de uma consciência apostada no futuro. ${ }^{32}$

Fora do território europeu, a ação missionária ocidental se desenvolveu impregnada de uma sensação de ameça, despejada de angústias, dúvidas, incertezas. $\mathrm{O}$ encontro com o diferente causou temor e ao mesmo tempo incitou a procura do que era estranho. Na maioria das vezes, prevalecia uma disputa ideológico-religiosa de ver o diferente como um Outro hostil, infamador, portanto, ameaçador.

O cristianismo ofereceu aos seus seguidores um sistema de normas morais ou de salvação para compensar os pecados terrenos dos homens e das mulheres. A Igreja "reconhecia a possibilidade de recorrer nos momentos difíceis, quando tinham que enfrentar as vicissitudes da vida, a forças sobrenaturais que emanavam de objetos ou locais". ${ }^{33}$ Aqui, conforme analisa Helen Ulhôa Pimentel, a religião como sistema explicativo do mundo, como um conjunto de elementos essenciais que compõe um todo como mito, dogmas, ritos e cerimônias, está associada pelos seus adeptos a mecanismos de controle social.

Havia o recurso do poder dos santos que operavam milagres e ofereciam proteção aos doentes, das relíquias consideradas sagradas e das imagens de uso estilístico, que diziam infalivelmente o lugar que as pessoas ocupariam, caso elas não seguissem o caminho de Deus. Os próprios sacramentos tinham associação com o poder de cura como o batismo, que retirava o pecado original e a consagração da hóstia, que transformava o pão em corpo de Cristo. Todos esses elementos despertavam uma especie de culpabilidade nas consciências dos fiéis. ${ }^{34}$

Vale ressaltar que nem sempre a prática cotidiana de atos religiosos significou uma vida mais pura e cristã. $\mathrm{O}$ automatismo e a rotinização dessas práticas muitas vezes fizeram com que esvaziassem o sentido do rito. Daí os fiéis não encontrarem sentido para a solução das suas angústias.

$\mathrm{Na}$ América portuguesa, a doutrina protestante ainda era desconhecida e, mesmo a católica, era observada por poucos. Os fiéis cristãos moradores da colônia não tinham uma grande compreensão do que de fato representavam os

\footnotetext{
${ }^{32}$ DELUMEAU, Jean. Introdução: Uma história cultural do pecado. In. O Pecado e o medo: a culpabilização no ocidente (séculos 13-18) ; tradução de Álvaro Lorencini - Bauru, SP: EDUSC, p. 12, 2003.

${ }^{33}$ PIMENTEL, Helen Ulhôa, Op. Cit. p. 14

${ }^{34}$ Idem, p. 13
} 
ensinamentos da Igreja. A doutrina sobre o pecado era vagamente conhecida, mas o discurso atemorizante era presente. Apesar disso, a figura do Diabo e a sua presença havia entrado na vida de todos com a autorização do clero. Imputando o medo nos fiéis, ninguém negava ou questionava a sua existência, nem os poderes a ele atribuídos.

No seu todo, conforme analisa Charles Boxer, os missionários europeus eram os apóstolos modernos, quer fossem eles sacerdotes, padres, frades, ou evangelistas protestantes. Todos estavam predispostos a se considerarem os portadores não só de uma religião superior, como de uma cultura superior. Estavam convencidos da superioridade moral e material do cristianismo ocidental, apesar de serem "recebedores inconscientes e dadores conscientes. Isto é: não estavam conscientemente preparados para receber, ou adaptarem-se às condições locais e ao meio ambiente; pelo contrário, estavam mesmo convencidos da superioridade da sua cultura e modo de vida". 35

O estudo do imaginário português (e europeu), projetado na América portuguesa é um elemento importante para entender a relação heterológica que se verificava pela negação de um Outro ameaçador, infamador que fazia parte da cultura do Novo Mundo ${ }^{36}$. Laura de Mello e Souza mergulha neste tema e delineia representações extremamente contraditórias sobre o Brasil.

A historiadora parte do imaginário sobre a América para entender o seu substrato demonológico. Para isso, Mello descreve a constante tensão entre "o racional e o maravilhoso, entre o pensamento laico e o religioso, entre o poder de Deus e do Diabo, embate, enfim entre o Bem e o Mal". ${ }^{37}$ O maniqueísmo presente nesta época, ocupava lugar de destaque na mentalidade religiosa, que estava presente nos diferentes setores da vida cotidiana da América Portuguesa.

\footnotetext{
${ }^{35}$ A.da Silva Rego. Portuguese Discoveries and Modern Missionary Apostolate. publicado nos debates de uma conferência em Estocolmo em 1960 e reeditado in Temas sociomissionológicos e históricos. Lisboa, 1962, p. 45-49 Apud BOXER, C. R. Interaccões Culturais. In. A Igreja e a Expansão Ibérica (14401770). Lisboa: edições 70, 1978, p. 56.

${ }^{36}$ A hetereologia, ciência do outro, é percebida nos relatos de viajantes que reportam, inventam e descobrem o seu próprio lugar de origem. Assim, no século XVII a Igreja Católica instaurou a caça às bruxas e os manuais demonológicos na Europa, tal como os europeus, com apoio da Igreja - esmeraramse em eliminar as idolatrias dos nativos por meio da catequese. Dois reversos de uma mesma mentalidade: o diferente, aos olhos do individuo, do Estado e da Igreja. BELLOTI, Karina Kosiki. Identidade, Alteridade e religião na historiografia colonial. São Paulo. In. Revista de História e Estudos Culturais., 1/22, 2005. p. 12 (com adaptações)

${ }^{37}$ SOUZA, Laura de Melo e. Inferno Atlântico: Demonologia e colonização séculos XVI - XVIII. São Paulo, Companhia das Letras, 1993. p. 15.
} 
Herdeira dessa dualidade, a colonização do Brasil oscilou entre o maravilhoso, espaço de utopia, da liberdade de um mundo cuja selvageria poderia ser indício de uma felicidade mais próxima da representação do paraíso, e o terrível, espaço de monstros e pesadelos, domínio de Lúcifer que espalhava a lascívia e a sensualidade entre os colonos e os destinava ao fracasso, à perdição. Eram ambas leituras européias do encontro com o outro, com o diferente e que informavam a maneira como deveriam se posicionar frente ao novo. ${ }^{38}$

Souza considera a demonologia como a ciência teológica mais bem repartida entre conquistadores, colonizadores, e especialistas como os missionários e eclesiásticos em geral. $\mathrm{O}$ imaginário que perpassava os escritos das primeiras décadas da colonização buscava em sua maioria diferenciar o que pertencia aos domínios da religião e da magia, de Deus e do diabo, passando a condenar a superstição - "identificada pela maioria dos autores, antes com o que se opunha à ideologia da Igreja do que com o irracional propriamente dito: num mundo em que as barreiras entre Magia, Religião e mesmo Ciência mal estavam traçadas, não era fácil esclarecer o que pertencia a uma e a outra esfera". 39

Segundo Belloti, essa visão demonológica sobre a América, os ameríndios e os negros impediu que os conquistadores compreendessem a cultura dos dominados. Ao incorporar práticas indígenas ao rol das ações demoníacas, o europeus ampliaram o sentido de superstição, de maldade, de feitiçaria, revivendo com cores mais fortes as analogias com o sabá, o canibalismo e magia ${ }^{40}$. Completa Mello e Souza:

A demonologia surge, assim, como muito mais do que um conjunto de tratados referentes à perseguição de bruxas, e se espraia por outras obras além dos manuais de feitiçaria, sendo possível detectar uma demonologia em sermões católicos, nos textos de pregação protestante, enfim, em toda a produção epistolar e tratadística voltada para a descrição da natureza e do continente americano e dos hábitos e costumes de seus habitantes. ${ }^{41}$

Neste sentido, Laura de Mello e Souza parte do imaginário sobre a América, sem perder de vista o social, para buscar compreender os modos de sentir dessa

\footnotetext{
${ }^{38}$ PIMENTEL, Helen Ulhôa, Op. Cit. p. 47

${ }^{39}$ Ibdem, p. 24

${ }^{40}$ BELLOTI, Karina Kosiki. Identidade, Alteridade e religião na historiografia colonial. São Paulo. In. Revista de História e Estudos Culturais., 1/22, 2005. p. 13

${ }^{41}$ SOUZA, Op. Cit, p. 24
} 
sociedade; definidos a partir de um conjunto difuso de representações, símbolos e imagens demonológicas. O olhar da historiadora vislumbra a circularidade de idéias na América portuguesa, e além disso nos lembra a importância de se estudar a história do imaginário, que determina e delimita o estudo de determinado campo historiográfico abalizado nas imagens mentais, discursivas e visuais.

Em estudo sobre a feitiçaria em Portugal, Paiva enfatiza que apesar de as classes dominantes e populares não formarem campos integralmente homogêneos e de suas concepções sobre o mundo serem distintas, elas sofrem influências recíprocas. O pesquisador constata, com base na análise de textos eruditos onde se debatem concepções mágicas sobre o mundo, que os teólogos e canonistas católicos se mostravam mais interessados nesse debate. ${ }^{42}$ Assim, o autor conclui que apesar de reconhecer essa circulação de saberes entre ambas as culturas ${ }^{43}$, "o Demônio aterrizou primeiro os doutos para só depois ser incorporado pela cultura popular, a partir do que passaram a comungar a idéia de que a presença do mal, do inimigo de Deus, era a força a ser derrotada, era a luta a ser empreendida". ${ }^{44}$

Paiva assinala que em matéria de repressão necessária aos crimes de feitiçaria nunca houve um movimento intenso de caça às bruxas. Na obra Bruxaria e Superstição num País sem caça às Bruxas, o autor evidencia que apesar do elevado número de denúncias, poucas eram devidamente analisadas, isso demonstra uma postura de maior prudência por parte da Inquisição portuguesa, nos casos de denunciações de práticas mágico-religiosas. Comenta Pimentel: "Para ele a Igreja e a Inquisição que se ocuparam destas questões não as colocaram em posição central e as reflexões mais profundas produzidas sobre o tema versam sobre a doutrina do pacto diabólico que em última instância definia se a ação era herética ou não. A heresia era o que interessava e que definia a gravidade do fato". 45

Baseado nisso, Portugal teria conseguido manter uma unidade ortodoxa, dogmática e doutrinal, e, além disso, manter os privilégios institucionais da Igreja e dos membros mais elevados dentro da hierarquia da Igreja Católica. No entanto, isso não implica a total ausência de controle dos agentes de práticas mágicas, por

\footnotetext{
${ }^{42}$ PIMENTEL, Op. Cit. p. 37 Apud PAIVA, Op. Cit. p. 352.

${ }^{43} \mathrm{O}$ termo "circularidades" permite reconstruir a dinâmica entre a cultura das classes dominantes e a das classes subalternas. Segundo Guinsburg, temos, por um lado, dicotomia cultural, mas, por outro, circularidade, influxo recíproco entre ambas as culturas, particularmente intenso na primeira metade do século XVI. GINZBURG, Carlo. O queijo e os vermes - O universo de um moleiro no século XVI. São Paulo, Companhia das Letras, 2006.

${ }^{44}$ PIMENTEL, Op. Cit. p. 18.

${ }^{45}$ Idem, p. 37
} 
instâncias que tinham competência nessa área, nomeadamente a justiça episcopal e a Inquisição. A tentativa de estabelecer quem estava por trás de certas práticas e crenças era uma das preocupações dos eclesiásticos e elites portuguesas.

Paiva enfatiza que a brandura da repressão portuguesa se localizava nos próprios denunciados, e não nos inquisidores, visto uma certa resistência dos acusados em não confessar o pacto com o diabo e nem renegar a Deus; elementos essenciais à condenação perpétua dos acusados. O pesquisador explica que a crença em Deus e a repugnância ao Diabo estariam tão arraigadas nas crenças de raízes populares, que, para eles, era inadmissível realizar pacto com o diabo e renegar a Deus.

No espaço luso da América as coisas parecem ter sido diferentes porque estavam em jogo outros fenômenos culturais. A natureza da população colonial impôs novas preocupações, visto a interpenetração de populações de procedências e credos diferenciados; o entrelaçamento de tradições. Laura de Mello e Souza avança neste assunto e examina com mais detalhes o universo mágico e religioso do Brasil colonial. Ao contrário de Paiva, a autora mostra que a atuação da Inquisição na Colônia foi permeada de muita habilidade, vigília e repressão. No mundo ordinário colonial, surgia a necessidade de nomear e definir o desconhecido, o desviante. Souza nos conta que: "Os habitantes das terras longínquas que os europeus acreditavam serem fantásticos constituíam uma outra humanidade, fantástica também, e monstruosa", ${ }^{46}$ por isso desarmônica.

Com a inserção do Novo Mundo no horizonte europeu, o imaginário monstruoso se associou aos habitantes de uma América, que segundo Laura, à diferença do que acontecia na Europa, passou a ser demonizada. Assim, feitiçaria e religiosidade popular passaram, então, a representar um conjunto de características multifacetadas que agregavam concepções diversas. As crenças coloniais se compunham de uma familiaridade com o divino, com as coisas da religião, para que o Deus católico se tornasse sempre presente, inatingível, apesar de determinados signos da Igreja Reformada e da identificação entre o diabo e o sexo também comporem essas práticas, possíveis elementos de corte com a moral cristã.

Segundo Laura de Mello e Souza, a repressão e o repúdio à feitiçaria colonial ajudam a entender o comportamento das elites ante essas práticas. Afirma a

\footnotetext{
${ }^{46}$ SOUZA, Op. Cit. 1986, p. 49
} 
autora que o contexto de caça às bruxas operou um processo de rejeição do universo popular por parte do erudito. "As reformas religiosas européias e a consolidação dos modernos aparelhos de poder ajudaram a aprofundar essa fissura”. ${ }^{47}$

A feitiçaria moderna surgiria como fruto do desequilíbrio europeu, representado pelas guerras de religião, as fogueiras que queimavam feiticeiras e heréticos em geral. Deste modo, foi a partir da separação operada entre as culturas erudita e popular, que surgiu o discurso repressivo e elevou a figura do diabo como centro dos ritos das práticas mágicas, do folclore, provocando, assim, alterações no seu significado. Completa a autora: "constatar isto é aventar a possibilidade de que as profundas alterações em curso na abertura da Época Moderna desestruturem simultaneamente o saber erudito e popular, fazendo com que esta desestruturação interaja nos diferentes níveis de modo simultâneo e intricado". 48

$\mathrm{Na}$ maioria dos processos inquisitoriais da época encontramos a crença dos inquisidores, dos denunciantes e dos denunciados na "existência de feitiçarias, bruxarias, curandeirismos, da crença na presença concreta do Demônio no mundo, da sua capacidade de agir sobre as pessoas". ${ }^{49}$ Posturas vigilantes e cuidadosas eram comuns à época e pessoas que acreditavam na existência do Diabo em sua capacidade de influenciar homens e principalmente mulheres.

É neste contexto que as visitações do Santo Ofício e as Devassas constituíram momentos de efervescência e de uma ruptura que aprofundava e expunha os desníveis entre o Velho e Novo mundo; entre o universo inquisitorial e o da religiosidade popular. Afinal, como evitar o conflito entre a rigidez religiosa dos Inquisidores e a realidade do universo mágico colonial? Mais importante do que saber se determinada feiticeira fazia porções de amor, ou se um colono tinha em sua casa um crucifixo invertido, ou se um outro era luterano e duvidava do purgatório, há pois que compreender as atitudes e reações de um e outro à luz de uma religiosidade híbrida. Ou seja, entender particularmente como a experiência religiosa de mulheres é marcada na colônia. Além disso, examinar como se deu o contato cultural e o estranhamento dos europeus com as condições de vida nos trópicos.

\footnotetext{
${ }^{47}$ Idem, p. 376

${ }^{48} \mathrm{Ibdem}$

${ }^{49}$ PIMENTEL, Op. Cit. p. 17.
} 


\section{Capítulo 2. Vivências religiosas femininas: As diversas faces de uma experiência}

A crença em forças sobrenaturais interferindo na vida dos homens e das mulheres era um fenômeno presente que atingia a todas as camadas sociais, gêneros, etnias. Seus agentes, no entanto, foram sendo selecionados aos poucos, principalmente entre as mulheres e os populares. Desta forma, de acordo com o pensamento europeu da época a mulher foi em larga medida representada por uma "essência" fundamentalmente imperfeita e má.

Um grande aporte empírico para evidenciar o sentido pragmático, sobretudo, social, que a Igreja Católica impunha à experiência religiosa feminina na América portuguesa são as documentações inquisitoriais das visitações do Santo Ofício às partes do Brasil. Em toda a documentação da época "seja a eclesiástica, a inquisitorial ou a civil, há afirmação da existência de feitiçarias, bruxarias, curandeirismo, da crença na presença concreta do Demônio no mundo, da sua capacidade de agir sobre as pessoas". ${ }^{50}$ Conferia-se à religião um caráter social na medida em que o papel de reestruturar a vida das religiosas ou desviantes era chave para construir uma crença com base na disciplina da moralidade cristã e européia.

No caso específico do Brasil, a historiografia tem confirmado que as mulheres foram muito mais acusadas do que os homens. Ainda que estes realizassem algumas práticas como a adivinhação, ou mesmo a feitiçaria, predominava a prática de acusar preferencialmente as mulheres pelo uso de suas magias.

O olhar lançado sobre as feiticeiras da época era mediado por uma série de representações' dentre as quais as de gênero, que passa a determinar padrões de comportamento dentro do que era considerado ou não como desviante. ${ }^{51}$ Baseado nisso, em conformidade com o discurso dominante da época, a mulher foi representada como um ser poderoso e mais vulnerável do que os homens às tentações da carne.

\footnotetext{
${ }^{50}$ Idem

${ }^{51}$ Neste trabalho, considera-se que as representações acontecem a partir das reconstruções feitas pela realidade do passado, contendo sentidos ocultos e internalizando no inconsciente coletivo uma coerência de sentido dentro de um dado tempo e de uma dada sociedade. Desta forma, "Representar é a presentificação de um ausente; é um apresentar de novo, que dá a ver uma ausência. A idéia central é, pois, a da substituição, que recoloca uma ausência e torna sensível uma presença”. PESAVENTO, Sandra Jatahy. Mudanças epistemológicas: a entrada em cena de um novo olhar. In. História e História Cultural. Belo Horizonte: Autêntica, p. 40, 2003.
} 
Delumeau sustentava que o discurso misógino recaía sobre a mulher. ${ }^{52}$ Este autor observa que o sexo feminino era visto na mentalidade européia como cheio de defeitos e mais vulneráveis às investidas do Diabo. Assim sendo, o principal objetivo do Diabo era corromper a fé de mulheres que são, por natureza, mais traiçoeiras, fracas, maliciosas, mais carnais que os homens, portanto, pertencentes às forças do mal, por isso a preferência em atacá-las.

Apesar de a cúria eclesiástico reconhecer a existência de mulheres de recato, imunes á ação do universo diabólico, prevalecia o discurso de que o gênero feminino era fraco. Assim, temos dois tipos de mulheres: a boa e a má. Segundo Pimentel: "para ambas são utilizados adjetivos extremamente fortes como: perversa, víbora, colérica, maliciosa, traiçoeira, contra virtuosa, virgem, santa, devota, propiciadoras de beatitude aos homens e salvadoras de nações, terras e cidades". ${ }^{53}$

Na linha de Pimentel, o processo de civilização da Igreja e do Estado, trazia fundamentalmente essa visão "essencialista" que impunha um modelo de mulher que cria identidades fixas, que qualifica as características masculinas e desvaloriza as femininas. $\mathrm{O}$ regime de verdade se produz aqui pensando as distinções entre o verdadeiro e o falso, o bem e o mal, o bom e o mau, de acordo com atuações que expressam valores específicos e buscam considerar os rumos e interesses da ortodoxia Católica. A dialética entre as várias figuras de mulher presentes na colônia nos permite enxergar de que forma o gênero feminino participou do "processo de colonização, transcendendo uma natureza que é parte de sua herança social e metafísica e, finalmente, de como domesticou quase todos os elementos que pudessem fazer da mulher uma ameaça à sociedade". 54

Pensando em descobrir a lógica dos discursos normativos sobre o que a mulher deveria ser ou não, Del Priore encontra em documentos dos séculos XVI a XVIII, imagens recorrentemente associadas à opressão e a dominação da mulher. Nessa documentação, a mulher é vista como vítima constante da dor, do sofrimento, da solidão, da exploração física, emocional e sexual. As fontes sugerem um

\footnotetext{
${ }^{52}$ DELUMEAU, Jean. Os agentes de Satã: III. A mulher. In. História do Medo no Ocidente - 1300-1800. São Paulo, Schwarcz, 1996.

${ }^{53}$ SPRENGER, James e KRAMER, Heinrich. Malleus Maleficarum, o martelo das feiticeiras. Rio de Janeiro: Rosa dos Tempos, 1991 Apud PIMENTEL, Helen Ulhôa. Cultura Mágico-Supersticiosa. In. Universo Mágico Colonial. Feiticeiros e inquisidores nos dois primeiros séculos da colonização do Brasil. Brasília: UnB, 2005.

${ }^{54}$ PRIORI, Mary del. Introdução. In. Ao sul do corpo: condição feminina, maternidades e mentalidades no Brasil Colônia. Rio de Janeiro: José Olympio; Brasília, DF: Edunb, p. 20, 1993.
} 
conjunto determinado de regras que identificam a lógica de uma época e estruturas de poder especificas, que reagiam, puniam e resistiam a diferentes situações de maneiras diferenciadas. ${ }^{55}$

A mentalidade colonial foi sendo vagarosamente penetrada por um tipo de discurso que visava conformar e adestrar o comportamento feminino. Tal discurso foi propagado, com conteúdo e objetivos específicos, através dos sermões dominicais, nas regras das irmandades, nos contos populares, nos confessionários.

Depois do concílio de Trento, fora imposta uma nova lógica de comportamento, em que a maneira de vestir, os gestos, hábitos e o olhar seguiam, como um todo, a pressão organizadora da Reforma católica. Com efeito, o século XVI é de um esforço imenso de controle dos comportamentos. São as normas de uma civilidade que projeta o indivíduo para dentro de si mesmo numa busca disciplinadora e idealizada de virtudes.

As normas de controle se tornam mais severas a ponto de encerrar o indivíduo num conjunto de vigilância cada vez mais rigorosa. Segundo Revel: "Constituem-se à margem da vida coletiva espaços protegidos que são objeto de uma revalorização, sendo o primeiro dele o foro familiar". 56

$\mathrm{Na}$ obra $O$ processo civilizador - uma história de costumes - Norbert Elias ${ }^{57}$ corrobora esta idéia ao mostrar o processo civilizatório como um fenômeno que transforma as sociedades ocidentais e modifica comportamentos a partir de um modelo de educação válido para um grande número de pessoas, constituindo assim, como dito anteriormente, um molde da verdade. Essa onda de mudanças marcou toda a cristandade ocidental. Além disso, foi acompanhada por uma mentalidade de culpabilização obsessiva, "de uma promoção sem precedentes da interiorização e da consciência moral". ${ }^{58}$ Completa Del Priori:

A espontaneidade dos atos começava a dobrar-se à regra, ao recalque, à interiorização da vida social. Emergia um claro paralelismo entre a privatização do eu e a apropriação privada dos meios de produção. Nascia uma nova ética sexual a bordo de uma nova sensibilidade, enquanto a sociedade ocidental reabsorvia os excessos de sua

\footnotetext{
${ }^{55}$ Idem, p. 16

${ }^{56}$ REVEL, Jacques. Os usos da civilidade. In. CHARTIER, Roger. (org); tradução Hildegard Feist. História da Vida Privada 3: da Renascença ao Século das Luzes. São Paulo: Companhia das Letras. p. 169, 1991.

${ }^{57}$ ELIAS, Norbert. O desenvolvimento do Conceito de Civilité. In. O Processo Civilizador - Uma História de Costumes. Brasil, 1987.

${ }^{58}$ DELUMEAU, Op. Cit, p. 9
} 
sexualidade num discurso interminável, que parecia enterrar as práticas sob uma montanha de comentários religiosos, jurídicos e médicos. ${ }^{59}$

De fato, a mudança de comportamento e a imbricação das esferas do público e do privado é uma das características marcantes da Época Moderna. Encarado em conjunto, estes aspectos revelam a Colônia como prolongamento, ou seja, alargamento da metrópole, mas, ao mesmo tempo, a sua negação. Foi neste espaço de ambigüidade e contradição que os homens e mulheres improvisaram, à sua maneira, novas formas de viver - inclusive para poderem reagir ante aos imprevistos do cotidiano, suportar o acaso de situações inéditas e neutralizar as angústias diárias. Vivências que, levavam determinadas mulheres ao isolamento, ao ponto de ameaçar a sua própria vida, ou então, no limite, inviabilizavam a sua intimidade.

No território grandioso que aos poucos foi se transformando em Brasil, o isolamento, a precariedade das vivências cotidianas e religiosas de existência e a força disciplinadora dos padrões opostos à intimidade se tornaram marcantes. A concentração de poder das autoridades coloniais constituiu um fator de tensão para a sociedade da época. Inexistindo, em prática, qualquer limitação ao pleno exercício de seu poder, estes intervinham da forma que lhes parecessem melhor na vida e trajetória de pessoas comuns, ou mesmo de qualquer habitante "maior" sob sua jurisdição. ${ }^{60}$ É dessas privações insólitas e improvisadas de que estamos falando.

O discurso moralista modernizador muitas vezes foi construído com base no código moral que expressava conselhos e advertências sobre a conduta feminina e que revelava o ideal de mulher e da sua vivência religiosa numa determinada sociedade. A honra da mulher era algo que, por extensão, dizia respeito também aos homens, à Igreja e ao Estado. Era um bem pessoal feminino, mas também um bem público, da "casa grande" que caminhava de acordo com os bons costumes delineado na época. ${ }^{61}$

O estudo sobre as honradas e devotas permite uma análise mais acurada dos papéis sociais femininos, e das imagens criadas pelas sociedades sobre as mulheres. Nos documentos examinados por Mezan, é a noção de honra que expressa o bom

\footnotetext{
${ }^{59}$ PRIORI, Op. Cit, p. 27.

${ }^{60}$ A ver; FIQUEIREDO, Luciano. O avesso da memória: cotidiano e trabalho da mulher em Minas Gerais no século XVIII. Rio de Janeiro: José Olympio; Brasília: Edunb, 1993.

${ }^{61}$ FREYRE, Gilberto. Casa-grande \& senzala. Rio de Janeiro: Record, 1999.
} 
comportamento feminino em relação à conduta sexual. "Virtude é assim a maneira como a honra se manifesta nas mulheres e sua principal justificação". ${ }^{62}$

Assim, a virtude masculina está ligada a uma característica cívica e a honra à determinada moralidade. A figura do homem virtuoso é representada por um homem moderado, forte, que sabe governar a si mesmo, principalmente diante de Outros. No caso feminino, o que se tem é o inverso da honra masculina. A mulher virtuosa é a casta, a pura, a fiel ao marido, a honrada. Segundo Mezan: "neste sentido, a honra feminina estava longe de ser um privilégio de classe - como muitas vezes foi considerado para os homens -, mas um bem que todas as mulheres possuíam desde que o preservassem virtuosamente através da castidade ou da fidelidade". ${ }^{63}$

Para os homens, o inverso da honra era a covardia, por outro lado, a desonra da mulher era um estigma de ambos e desencadeava no âmbito da vida pública, já que era o olhar do Outro que determinava se a mulher era ou não uma figura honrada, em função dessa vida em sociedade que as pessoas criavam uma auto imagem. A honra era parte das esferas públicas e privadas, levando em conta que as opiniões externas interferiam na vida individual. Portanto, "manter a honra significava, antes de mais nada, manter as aparências". 64 Cabe ressaltar aqui que as esferas do público e do privado já não estão completamente distintas, mas ainda se encontram ambivalentes.

As estruturas sociais pediam por um controle emocional e sexual que não desviasse os comportamentos femininos do que era hegemônico na época. Baseado nesse discurso normativo colonial, a Igreja impedia que as mulheres tivessem outros papéis que não os determinados pela vida familiar ou então aqueles de uma vida mais casta, ou mesmo honrada. O apostolado católico, detentor de um forte monopólio religioso e ideológico na organização da América portuguesa, impregnava todos os conhecimentos e ajudava a conservar a submissão feminina, mais tarde transformada em projeto de colonização, ao mesmo tempo portuguesa e cristã.

\footnotetext{
${ }^{62}$ ALGRANTI, Leila Mezan. Introdução. In. Honradas e devotas: mulheres da Colônia: Condição feminina nos conventos e recolhimentos do Sudeste do Brasil, 1750 - 1822. Rio de Janeiro: José Olympio; Brasília: Edunb, p. 111, 1993.

${ }^{63}$ Idem, p. 112.

${ }^{64}$ Ibdem, p. 112.
} 
Apesar deste trabalho não abarcar análises historiográficas do século XVIII, vale ressaltar o exame de Mezan, que, relendo algumas fontes impressas do período já citado e obras clássicas da historiografia brasileira nota que eram muitas as instituições de reclusão feminina, algumas ligadas às ordens religiosas ou irmandades leigas. Segundo esta historiadora, o que a época moderna traz de novo é o surgimento destas instituiçõoes leigas de reclusão destinadas às mulheres, pensando em preservar a honra e controlar a sexualidade feminina. Trata-se de mais um elemento próprio do processo de individualidade presente na modernidade.

A criação dos recolhimentos no Brasil era vista com bons olhos, já que a coroa proibiu a existência de conventos até muito tarde e enviar filhas para a metrópole era muito caro. Estas instituições representavam a melhor maneira de socializar as meninas, e prepará-las para o casamento, tirando-lhes os defeitos de uma educação doméstica. ${ }^{65}$ Completa Maria Beatriz Nizza da Silva

\begin{abstract}
Ali seriam educadas as filhas das casas principais, as dos homens ricos e ainda as de gente ordinária. Ali se ensinaria a pureza dos costumes, enquanto boas mestras as punham a praticar o trabalho da costura, de fazer rendas, bordados e outras ocupações semelhantes, evitando-se assim a molidão, a indolência e a preguiça. Resta saber se esta socialização comunitária trouxe os resultados desejados. ${ }^{66}$
\end{abstract}

Após o concílio de Trento, a clausura imposta às mulheres acabou por condicionar a sujeição destas ao homem e a hierarquia eclesiástica, quer fosse em relação aos bispos, padres, ou ainda ao papa. $\mathrm{O}$ enclausuramento era praticado em nome de princípios morais, da preservação dos bons costumes e da castidade feminina, questões muito presentes no imaginário da colônia portuguesa.

Leila Mezan esclarece que apesar de estarmos acostumados a pensar nas instituições de clausura como espaços fechado ao exterior, essas instituições são criadas através de normas que expressam os sentimentos e os valores dos indivíduos de forma dinâmica, pois os limites entre essas instituições e a sociedade não

\footnotetext{
${ }^{65}$ Segundo Emanuel Araújo, documentos básicos sobre a educação feminina são os estatutos elaborados pelo bispo Azeredo Coutinho para dois recolhimentos em Pernambuco, ambos publicados em 1978. Por intermédio desses textos sabemos que as mestras do recolhimento ensinavam às meninas os princípios da religião, a fim de protegê-las dos defeitos do seu sexo.

${ }^{66}$ SILVA, Maria Beatriz Nizza da. Mulheres na Colônia: uma história a ser escrita. In. Revista Ler História. Ano, 2000/nº 39/ 59-79, p. 70
} 
existem e possuem, por isso, certa dose de flexibilidade. São espaços que permitem captar sua ligação com a sociedade. ${ }^{67}$

Os recolhimentos sugerem um caráter educativo para mulheres que não corresponde a expectativa da sociedade, ou seja, a de boas esposas com filhas/os impecáveis. No entanto, algumas recolhidas entravam nestas instituições para esperar por um bom casamento. Comenta Algranti: "Vistos dessa forma - no interior na qual o poder era exercido pelos homens - os recolhimentos começaram a se configurar como uma espécie de apêndice do convento. Neles as mulheres levavam uma vida conventual, sem, contudo fazerem votos perpétuos". ${ }^{68}$ O que permite uma análise mais ampla da reclusão feminina no período colonial, e trás à tona aspectos importantes e pouco conhecidos da vivência religiosa feminina da época.

A questão da educação feminina também foi afetada nas reformulações pósreforma da Igreja, já que o papel da família "no projeto de evangelização tridentino concedeu à esposa e à mãe um novo papel: o de educadora. Era preciso prepará-la para que o desempenhasse". ${ }^{69}$ Uma outra preocupação era encontrar uma nova alternativa para aquelas que não se casassem, ou seja, estas seriam levadas para estabelecimentos de reclusão, onde desenvolveriam atividades ditas femininas como leituras, trabalhos de agulha, entre outras.

Outra forma de vida religiosa era o recolhimento domiciliar. Para muitas cristãs recolher-se do mundo significava a verdadeira busca da perfeição, com isso, inúmeras católicas fervorosas, não encontrando instituições religiosas onde pudessem se dedicar de corpo e alma a Deus, fizeram de suas próprias casas um espaço de claustro ou recolhimento.

A casa é o espaço privilegiado para o desempenho das atividades privadas e religiosas das recolhidas. Conforme nos deixou a tradição oral, em muitas casas antigas, podia-se ver uma série de imagens, quadros e talismãs que sinalizavam a presença do sagrado no espaço privado residencial. Seguindo o costume português, os objetos símbolos da fé cristã estavam sempre visíveis. As mais devotas, tinham sempre o rosário dependurado na cabeceira da cama e sempre quando levantavam ajoelhavam-se no chão, recitavam a ave-maria, o pai-nosso, o credo e a salve

\footnotetext{
${ }^{67}$ ALGRANTI, Op. Cit, p. 51

${ }^{68}$ Idem, p. 3

${ }^{69}$ Ibdem, p. 47
} 
rainha, orações básicas da Igreja Católica. Cabe, inclusive, acrescentar que mesmo os desviantes da ortodoxia católica sabiam decorado essas orações, pois ao serem inquiridos pelo Santo Ofício, demonstrar ter conhecimento das orações básicas era uma das "provas" de fé de todos os inquiridos.

Luiz Mott comenta o caso de recolhidas no espaço privado do nordeste brasileiro. Nos conta o autor que em Recife viveram sete irmãs, filhas de pessoas nobres e ricas, em que, mortos os seus pais se conservaram na própria casa com os resguardos de um mosteiro observante. Na casa havia um oratório onde nele perseveravam durante várias horas de joelho, orando mental e vocalmente, derramando, nesta celebração, muitas lágrimas. De casa as irmãs saiam apenas para frequientar as missas, se confessar e comungar na Igreja. Acrescenta Mott que os vizinhos as viam tão modestamente cobertas, que não se achava quem lhes vissem os rostos. ${ }^{70}$

Recolher-se do mundo significava a busca da verdadeira perfeição mística, daí o prestígio para parentes e/ou agregados em ter um santo, penitente, beato, ou recolhida dentro de casa. Era um status que oferecia vantagens materiais e um forte sortilégio social. Vale ressaltar que nos processos inquisitoriais várias devotas passaram a forjar visões e efeitos sobrenaturais com vista ao reconhecimento social e usufruto das mordomias conseguidas na função de devota/o.

Podemos vislumbrar com maior clareza o apontamento que o autor faz da vida religiosa dessas mulheres através da problemática historiográfica da história social. Para isso é necessário refletir sobre os modos e estratégias dessas organizações, as relações sociais (entre os grupos e os indivíduos no seu interior) e além disso, os processos de transformação da sociedade.

Luís Mott ressalta o papel fundamental da população nos assuntos relacionados à santidade. A população glorificou e venerou como servas e servos de Deus a certas criaturas que posteriormente foram considerados santas e santos malditos, ou seja, devotos/as não reconhecidos oficialmente pela Igreja católica. ${ }^{71}$

\footnotetext{
${ }^{70}$ MOTT, Luis. Cotidiano e vivência religiosa: entre a capela e o calundu. In. SOUZA, Laura de Mello e.(org) História da vida privada no Brasil: cotidiano e vida privada na América portuguesa. São Paulo: Companhia das Letras, p. 180, 1997.

${ }^{71}$ Laura de Melo e Souza procurou ressaltar em seu trabalho o degredo para o Brasil no século XVII de várias mulheres acusadas de falsa santidade. Estas mulheres se declaravam santas e proclamavam suas virtudes, mas nelas o Santo Ofício não viu senão bruxas, revelando que a diferença na interpretação dos fenômenos devia muito à diferença dos níveis culturais dos agentes envolvidos nessa relação dialógica. As mulheres, quase todas pobres, de um lado, e do outro, o Santo Ofício, força política e jurídica, com suas concepções dogmáticas e eruditas acerca da religiosidade.
} 
Falsos santos, dentro da ótica cristã, significa aqui "todos aqueles que se fingindo enviados por Deus Nosso Senhor, ou possuídos pelos carismas do Espírito Santo, agiam por vanglória em proveito próprio, para fins terrenos ou materiais"72 Alguns exemplos: Joana D’arc, Santa Tereza Dávila e Santa Margarida Maria Alacoque.

O autor utiliza o processo inquisitorial de Rosa Maria Egipcíaca, retirada do arquivo da Torre do Tombo de Lisboa para exemplificar as duas faces de uma mulher negra que conseguiu ser considerada ao mesmo tempo santa e feiticeira.

Rosa Maria Egipcíaca foi uma africana capturada e vendida para o Novo Mundo aos 6 anos de idade. Foi batizada por ordem de seu primeiro proprietário, o mesmo que a deflorou aos 14 anos. Quando adulta, foi açoitada no pelourinho da vila de Mariana, nas Minas Gerais. Teria morrido anônima se não tivesse caído nas garras do Santo Ofício: destacou-se por uma série de fenômenos sobrenaturais e peripécias biográficas. Foi reputada como portadora de poderes sobrenaturais, conseguindo um numeroso séquiito de devotos não só entre a população, mas também nas elites.

Segundo Mott, a história de Rosa Egipcíaca é fenomenal por ela ter sido uma das únicas mulheres de cor - a que se tem conhecimento -, ex-escrava e exprostituta, em todo o mundo cristão, a fundar um "convento de recolhidas": o recolhimento de Nossa Senhora do Parto. Maria Egipcíaca chegou a merecer do provincial dos franciscanos do Largo da Carioca o título de "A flor do Rio de Janeiro". Uma Rosa negra, africana, ex-cativa e ex-prostituta é nomeada pelo alto clero do Brasil como "a maior santa do céu". Rosa e seu último proprietário, o padre Francisco Gonçalves Lopes, foram presos pela Santa Inquisição de Lisboa no ano de 1762, acusados de heresia e falso misticismo. Consta que o processo permanece inconcluso: não morreu no cárcere privado nem público, não foi queimada, nem degredada. ${ }^{73}$

Havia a necessidade de um modelo de santidade quando os níveis culturais ainda permaneciam indistintos: "Num século em que os santos e beatos constituíam legião, verdadeira "via láctea", as heterodoxias e desvios nem sempre eram

\footnotetext{
${ }^{72}$ MOTT, 1997, Op. Cit. p. 14

${ }^{73}$ MOTT, Luís. Introdução. In: Rosa Egipcíaca - Uma santa africana no Brasil. Rio de Janeiro, Bertrand Russel, p. 7-12, 1993
} 
facilmente identificáveis, e nesta matéria o Santo Ofício procurava antes pecar pelo excesso do que por falta". ${ }^{74}$

Rosa Egipcíaca não era o modelo ideal de santa que a Igreja Católica buscava. Existia nesse caso em particular uma ambigüidade desta mulher que desperta: inquietude e serenidade. Ela desfaz a noção da mulher virtuosa, casta e que exalta a virgindade na cultura cristã.

${ }^{74}$ SOUZA, Laura de Melo e. Inferno Atlântico: Demonologia e colonização séculos XVI - XVIII. São Paulo, Companhia das Letras, p. 114, 1993. 


\section{Capítulo 3. Sagrado e Profano: Um olhar sobre a colônia}

Para muitos católicos a religião na América portuguesa era um conjunto de práticas rotineiras e exteriores destinadas a cumprir obrigações da moralidade cristã. Isso implicava o não confronto com as autoridades eclesiásticas da época. Assim o medo dos castigos divinos e a adoção de uma vida religiosa aparecia como a melhor opção para quem acreditava na crença de um Deus Onipotente.

Havia católicos que se dedicavam abertamente à vida mística pelo prazer da autoflagelação física e/ou espiritual. Mott comenta que "muitos penitentes com certeza chegavam próximo ao orgasmo místico quando maceravam a carne com disciplinas e cilícios, ou aceitavam humildemente reprimendas e castigos mesmo quando eram inocentes das culpas de que se lhes acusava". ${ }^{75}$

Em todo caso, vale destacar que no Brasil colônia vigoraram desde os tipos mais autênticos e ardorosos, aos indiferentes e desviantes à religião oficial, a saber: católicos praticantes em teoria que cumpriam apenas rituais e deveres obrigatórios, mas como uma encenação pública e externa, guiada pelas aparências, do que como convicção. Haviam católicos displicentes que evitavam as cerimônias religiosas por indiferença e descaso espiritual, e os católicos não praticantes, boa parte de cristãos novos e desviantes em geral que para evitar a repressão inquisitorial, freqüentavam os rituais controlados pela hierarquia católica, mas que, no entanto, mantinham secretamente crenças heterodoxos. Assim, cristalizavam-se distintos tipos de práticas e vivências privadas que tinham a religião oficial como centro. ${ }^{76}$

Luiz Mott explica que nas Minas e no resto da Colônia, são freqüentes as denúncias contra homens e mulheres que recorriam ao uso de feitiçaria. As Constituições Primeiras do Arcebispado da Bahia consagra temas tocantes às superstições e feitiçarias nos domínios lusos. Apesar da magia do cotidiano religioso refletir grave pecado moral, Mott sugere que o clero e os comissários de guarda do Santo Ofício eram até mais severos do que o determinado no regimento, usando do arbítrio para vigiar, prender e intimidar os acusados de feitiçarias ${ }^{77}$.

\footnotetext{
${ }^{75}$ MOTT, Luis. 1997, Op. Cit. p. 17

${ }^{76}$ Idem

${ }^{77}$ A idéia esboçada por Luís Mott diverge das análises de José Pedro Paiva e Bithencourt, autores que consideram branda a atuação da Inquisição portuguesa no Brasil.
} 
O autor comenta casos que evidenciam a lógica da conduta na prática em detrimento da conduta normativa. ${ }^{78}$ Observa o pesquisador que a viúva pernambucana Teresa de Barros, preta forra, benzia mau olhado e curava bicheiras. Fazia ainda orações de Santa Helena, vestida em trajes de defunta com velas acesas. Maria da Cruz benzia olhados e carnes-quebradas, João, preto, escravo, benzia panos para estancar sague das feridas. Ana Rangel curava carne-quebrada e tirava sol com uma ventosa na cabeça dos enfermos. Jose Domingos benzia ferida de boca. $^{79}$

Nas Minas gerais, eram muitos os praticantes do calundu. "O estrondo dos atabaques, pandeiros, canzás, botijas e castanhetas, com tão horrendos alaridos que se me representou a confusão do inferno" ${ }^{80}$, impedia a continuação do que na época era considerado como a ação do diabo, ou melhor, o manifesto do seu culto. Comenta um pároco mineiro:

Pela obrigação que tenho, como Pároco, eu, Padre Manoel Ribeiro Soares, morador na Freguesia de Itaubira, denuncio que Angela Maria Gomes, preta forra, padeira, de nação Courá, é público e notório que é feiticeira há 8 anos e todas as noites, das terças e sextas feiras, depois da meia noite, na casa da dita, há uns calundus do inferno, estrondos horrendos que muitas vezes fazem tremer as casas em que vivo e numa noite de julho de 1759 , fez tais diabruras, que me privou do sono. Os ruidos que fazem no calundu parecem peças de artilharia, tão horrendas as algazarras e estrondos, roncos de porcos medonhos e cavalo relinchando e vários instrumentos do inferno e no fim gritaria de galinhas. ${ }^{81}$

Este depoimento revela o quão presente estavam as práticas africanas na sociedade colonial. E mostra que a presença no espaço privado certamente favorecia práticas de crendices nem sempre aprovadas pelo apostolado católico.

Laura de Mello também capta elementos místico-diabólicos desse universo mental, em geral, marcado pela temática da mulher como feiticeira ou bruxa, pelo medo do desastre, catástrofe cotidiana manifestada na linguagem discursiva eclesiástica, nas maneiras bruscas e rudes, no apreço por espetáculos violentos sensacionais. ${ }^{82}$ Segundo Souza, três casos ilustram bem esse estado de coisas.

\footnotetext{
${ }^{78}$ Laura de Mello e Souza interpreta isso como persistência da religiosidade popular européia.

${ }^{79}$ MOTT, Luis, Op. Cit, 1997 p. 195

${ }^{80}$ Idem

${ }^{81}$ Ibdem, p. 200

${ }^{82}$ SOUZA, 1993, Op. Cit. p. 137
} 
No primeiro deles, ocorrido no mês de agosto de 1734, em Lisboa, a jovem negra Marcelina Maria que recorreu ao Tribunal do Santo Ofício para confessar práticas mágicas. A negra recorrera a elas para se livrar dos rigores que sofria na condição de escrava, constantemente humilhada pelo senhor e pelos filhos dele. Desesperada, clamava pelo demônio para ajudá-la quando amassava o pão. O que chama a atenção no seu depoimento espontâneo é que sugere crença difundida, reveladora de aspecto curioso do imaginário feminino. ${ }^{83}$

Um ano antes, na mesma cidade de Lisboa, um outra escrava negra, chamada Catarina Maria, anãzinha, é acusada de bruxa junto à Inquisição, nascera nos matos de Angola, servia na casa de José Machado e o próprio senhor a denuncia, pois a casa toda a odiava e tinha medo dos feitiços e malefícios de que era capaz. A negra descreve o diabo na figura de um preto e além disso, referenda que o ato sexual com o diabo era penoso. A escrava endossa e repete todos os estereótipos demoníacos correntes na época, conhecidos da população e presentes na literatura demonológica em que os inquisidores se apoiavam para seus interrogatórios. $\mathrm{O}$ fato de o diabo ser negro, segundo Melo e Souza reforça certas versões européias acerca do Diabo mas que encontraria eco no imaginário de Catarina Maria por ser ela também negra. ${ }^{84}$

Por fim, o caso de sóror Maria do Rosário, chamada na Igreja de Maria Teresa Inácia, religiosa que, devido à vida pouco edificante que levava, viu-se expulsa do convento do Sacramento de Alcântara de Lisboa por sua provincial. À diferença das anteriores, era branca, e não negra. Maria do Rosário tinha a obsessão por suplício, tão típica desse imaginário e testemunhava que Satanás lhe mostrava uma enorme roda de navalhas com gente destroçada, ameaçando-a e dizendo-lhe que o mesmo que via lhe haviam de fazer a ela. ${ }^{85}$

Cunhada dentro do cristianismo, a figura da feiticeira traduzia-se em mulheres perversas, que participavam de orgias, tomavam a forma de um animal, tinham relações íntimas com os demônios e entregavam sua alma ao Diabo. Ela foi representada centralmente como a descendente de Eva, símbolo do pecado e da tentação, ainda que existisse uma tendência num certo sentido oposto a esta, com o

\footnotetext{
${ }^{83}$ Idem, p. 138

${ }^{84}$ Ibdem, p. 139

${ }^{85}$ Ibdem
} 
fortalecimento do culto à Virgem Maria ${ }^{86}$. Como as feiticeiras estavam muito distantes do ideal da Virgem, foram consideradas as agentes de satã, responsáveis pelos desvios dos homens. Assim os padres buscam os defeitos dessas mulheres, "as vêem como eternas Evas, na busca pelo prazer sexual, na busca pela dominação do homem". ${ }^{87}$

A feitiçaria colonial se fazia presente na vida cotidiana das populações, notadamente a das camadas mais pobres. Procuravam-se feiticeiras para filtros de amor, curandeirismo, para fechar feridas, para desvendar segredos. O encantamento, a maldição, e a benção também assumiam formas de magia. Com elas a comunidade partilhava as suas angústias, dúvidas, os seus medos, as incertezas. Seus depoimentos e a delação dos vizinhos aos tribunais de fé desvendavam parte importante do inconsciente coletivo e dos sonhos de cada um.

Deve-se observar, no entanto, que na feitiçaria colonial entram em jogo um conjunto de forças impessoais. O espírito pode ser evocado pela feiticeira e não vem, necessariamente, pela sua própria vontade. Os demônios evocados, neste caso, não têm a mesma personalidade do demônio cristão. Eles têm uma individualidade mais vaga, seus nomes se confundem com o de espécies e de pessoas, relacionandose com uma multidão de serem anônimos. A magia popular apela à intermediação dos espíritos; a magia cristã é indireta, age diretamente com a natureza e mantém um pacto íntimo com satã. ${ }^{88}$

Por toda a parte na colônia, a feitiçaria aparece como sinônimo de realização de desejos e de imagens sentimentais que por algum motivo cessa a reflexão e deixa a magia e a emoção renascerem. Aqui, portanto, "a magia é, em última análise, a objetivação do desejo. Porém, só merece o nome de magia quando se transforma num fenômeno análogo, passando da feitiçaria para o feiticeiro/a" ${ }^{89}$

Aqui, o sagrado e o profano são dois elementos de heterogeneidade absoluta. Quando um e outro se separam, o profano torna-se um protagonista perigoso, que deprava e diminui o poder do sagrado. A mulher, como dito anteriormente, excluída das cerimônias religiosas, termina passando por feiticeira e bruxa. O profano

\footnotetext{
${ }^{86}$ DELUMEAU, Jean. Os agentes de Satã: III. A mulher. In. História do Medo no Ocidente - 1300-1800. São Paulo, Schwarcz, 1996.

${ }^{87}$ VASCONCELOS, Vânia Nara Pereira. Visões sobre as mulheres na sociedade ocidental. In. Revista Ártemis. Ano, 2005/ no 1/10.

${ }^{88}$ BASTIDE, Roger. Bastide. Elementos de sociologia religiosa. São Paulo: Cadernos Pós Graduação de Ciências da Religião, 1990

${ }^{89}$ Idem, p. 19
} 
aproxima-se do impuro e domina o pólo negativo do mundo espiritual. Assim, os distanciamentos e aproximações do mágico e do religioso só podem ser compreendidos "como transformação secundária da distinção primitiva entre profano e sagrado". ${ }^{90}$ Completa Durkheim:

Todas as crenças religiosas conhecidas... supõem a classificação das coisas em dois gêneros opostos, designados por dois termos distintos que se traduzem pelas palavras profano e sagrado. Por sagrado não se deve entender os seres pessoais que se chamam deuses ou espíritos (rochedo, árvore, fonte, pedregulho, peça em madeira, casa, qualquer coisa pode ser sagrada). Um rito, uma palavra, uma fórmula podem ter esse carater. ${ }^{91}$

Em As formas elementares de vida religiosa, Durkheim explana que é mais apropriado procurar caracterizar os fenômenos elementares - mitos, dogmas, ritos, cerimônias - de que é formada toda a religião, antes do sistema produzido pela sua união dos mencionados fenômenos. Ora, afirma o autor, "um todo só pode ser definido em relação às partes que o formam". ${ }^{92}$

Segundo Bastide, esse método se impõe, mas existem fenômenos religiosos que não se vinculam a nenhuma religião em particular. Esses fenômenos religiosos incluemse em duas categorias: as crenças e os ritos. ${ }^{93}$ As primeiras são estados da opinião, são representações; os segundos, são modos de ação determinados. Essas categorias são traduzidas pelo que conhecemos de profano e sagrado.

Durkheim observa que a magia também é constituída de crenças e de ritos. Tem como "religião, seus mitos e seus dogmas, que são, apenas, mais rudimentares, porque, perseguindo fins técnicos e utilitários esta não perde seu tempo em especulações. Tem igualmente, suas cerimônias, suas purificações, suas orações, seus cantos, suas danças". 94 A fim de diferenciar a oposição tradicional entre o bem e o mal, o inteligível ao misterioso, o racional do irracional, enfim, o sagrado do profano, as crenças religiosas passaram a adotar esses sistemas de representações para as suas relações cotidianas. Completa o autor:

\footnotetext{
${ }^{90}$ Ibdem, p. 12

${ }^{91}$ DURKHEIM, Émile. Definição do fenômeno religioso e da religião. In: As formas elementares de vida religiosa (o sistema totêmico na Austrália). São Paulo: Paulus, 1989.

${ }^{92}$ Idem, p. 67

93 BASTIDE, Op. Cit.

${ }^{94}$ Ibdem, p. 74
} 
Para definir o sagrado do profano não resta senão a sua heterogeneidade [...]. O sagrado e o profano foram sempre e por toda a parte concebida pelo espírito humano como gêneros separados, como dois mundos entre os quais não há nada em comum. As energias que se manifestam em um não são simplesmente aquelas que se encontram no outro, com alguns graus a mais; são de outra natureza. Essa oposição foi concebida de maneiras diferentes, conforme as religiões. ${ }^{95}$

Particularizando a religião nos moldes dos domínios lusos, é evidente que quando uma religião se sobrepõe a outra, como é o caso do catolicismo na América portuguesa, suplantando o paganismo, o culto triunfante reage expurgando qualquer tipo de magia constituída de crenças e de ritos, não cristãos. Para que isso pudesse acontecer era preciso ter já o sentimento de que existia uma ordem natural das coisas o que fugia a esse princípio era visto com estranhamento.

\footnotetext{
${ }^{95}$ Ibdem, p. 70 ,
} 


\section{Considerações finais}

O pano de fundo sobre o qual as mulheres se moveram é então o das transformações religiosas que marcaram as relações metrópole-colônia e movimentaram o processo de colonização da América portuguesa. O exame de obras historiográficas recentes que versam sobre a agência de mulheres no exercício da religiosidade no ambiente cultural da colônia nos trouxe várias questões. Entre elas, a associação da Coroa portuguesa com a Igreja Católica com o propósito de normatizar o comportamento dos fiéis e os papéis femininos.

Se por um lado, a Igreja Católica se esforçava para manter normas de conduta moral que expressassem conselhos e advertências sobre o comportamento feminino, por outro, houve um grande número de mulheres que, mesmo sob os auspícios da Igreja, realizavam práticas mágico-religiosas em toda parte. A investigação das linhas de análise sobre o fenômeno devocional feminino nos permitiu perceber como a persistência de práticas pagãs preocupava os eclesiásticos e isso pode ser notado nos movimentos de reforma da época: tanto na Reforma protestante, como na reação católica. Ambas buscavam compreender e repensar o cristianismo.

A dialética entre as várias figuras de mulher presentes na colônia nos permitiu perceber de que formas o gênero feminino participou do processo de colonização, na América portuguesa. O estudo sobre as honradas e devotas, em particular, nos permitiu uma análise mais acurada dos papéis sociais femininos, bem como das imagens sociais sobre as mulheres.

As estruturas sociais requeriam o controle emocional e sexual das mulheres de modo a que não houvesse desvios comportamentais. Assim, a Igreja elaborava um discurso e realizava práticas que buscavam limitar a mulher aos papéis sociais e vida familiar convencional; uma mentalidade de privação em que determinadas noções como virgindade, casamento e monogamia eram situações de ensejo e conveniência, em contrapartida às transgressões civis e eclesiásticas de mulheres que, em meio ao universo religioso vigorante, ditava regras e costumes próprios.

A criação dos recolhimentos e ordens religiosas tinha exatamente o propósito de enclausurar as mulheres, pensando em preservar a honra e controlar a sexualidade feminina. Tratava-se de mais um elemento próprio do processo de individualidade e de controle presente na modernidade. Estas instituições representavam uma estratégia para 
socializar as meninas, e prepará-las para o casamento, tirando-lhes os defeitos de uma educação doméstica.

Outra forma de vida religiosa era a vida de recolhidas ditas honradas e virtuosas, que viveram uma vida recata e observante do regime monacal, ainda que no espaço doméstico. Para muitas cristãs, recolher-se do mundo significava a verdadeira busca da perfeição, com isso, inúmeras católicas fervorosas, não encontrando instituições religiosas onde pudessem se dedicar de corpo e alma a Deus, fizeram de suas próprias casas um espaço de claustro ou de recolhimento.

Com relação às análises existentes entre o sagrado e o profano, e, particularmente, entre magia e religião, o exame de Laura de Mello e Souza sintetiza o que desenvolvemos neste trabalho, quando a autora comenta que "no plano da magia e da religião, os sincretismos acabariam por se mostrar irreprimíveis e inextinguíveis; sobre elas incidiria sempre a marca ambígua da cultura popular, que misturava sagrado e profano" 96 .

Redescobrir todo este mundo simbólico de crenças mágico-religiosas significou entender melhor como as manifestações mágicas se desenrolava sob condições tão adversas aos padrões da época. A vida na colônia, mesmo solidária ou afastada das igrejas, traduz-se em atos de fé e elementos de crença individual. Tratou-se, portanto, de penetrar no universo feminino a fim de compreender a história de uma parcela da população cujo passado ainda nos é bastante desconhecido.

\footnotetext{
${ }^{96}$ SOUZA, 1986, Op. Cit.
} 


\section{Referências bibliográficas}

ALGRANTI, Leila Mezan. Introdução. In. Honradas e devotas: mulheres da Colônia: Condição feminina nos conventos e recolhimentos do Sudeste do Brasil, 1750 - 1822. Rio de Janeiro: José Olympio; Brasília: Edunb, 1993.

ANDRADE, Carlos Drummond. As impurezas do branco. Rio de Janeiro: J. Olympio, 1973.

AZZI, Riolando. Razão e Fé: o discurso da dominação colonial. São Paulo: Paulinas, 2001.

BASTIDE, Roger. Bastide. Elementos de sociologia religiosa. São Paulo: Cadernos Pós Graduação de Ciências da Religião, 1990

BELLOTI, Karina Kosiki. Identidade, Alteridade e religião na historiografia colonial. São Paulo. Revista de História e Estudos Culturais., 1/22, 2005.

BETHENCOURT, Francisco. "Campo religioso e Inquisição em Portugal no século XVI” In. AZEVEDO, Joaquim. (org). Estudos contemporâneos - religiosidade popular. Portugal: Porto, 1984.

CASTRO, Hebe. História Social. In. CARDOSO, Ciro F. S \& VAINFAS, Ronaldo (orgs). Domínios da História. Rio de Janeiro: Campus, 1997. p. 45-59

DE CERTEAU, M. A Invenção do Cotidiano. Petrópolis: Vozes, 1996.

CHAUNU, Pierre. Teoria Geral da Reforma Protestante. In. O Tempo das Reformas (1250-1550) II. A Reforma Protestante. Lisboa, edições 70, 1975.

DELUMEAU, Jean. Introdução: Uma história cultural do pecado. In. O Pecado e o medo: a culpabilização no ocidente (séculos 13-18) ; tradução de Álvaro Lorencini Bauru, SP: EDUSC, p. 12, 2003.

. Os agentes de Satã: III. A mulher. In. História do Medo no Ocidente

- 1300-1800. São Paulo, Schwarcz, 1996.

DURKHEIM, Émile. As formas elementares de vida religiosa (o sistema totêmico na Austrália). São Paulo: Paulus, 1989.

ELIAS, Norbert. O Processo Civilizador - Uma História de Costumes. Rio de Janeiro: Jorge Zahar, 1987.

FARIA, Miguel. Vaticínios e superstições 1524 - 1577. Revista Oceanos, Ano, 1993/nº $13 / 50-57$.

FIQUEIREDO, Luciano. $O$ avesso da memória: cotidiano e trabalho da mulher em Minas Gerais no século XVIII. Rio de Janeiro: José Olympio; Brasília: Edunb, 1993.

FREYRE, Gilberto. Casa-grande \& senzala. Rio de Janeiro: Record, 1999.

GINZBURG, Carlo. O queijo e os vermes - $O$ universo de um moleiro no século XVI. São Paulo: Companhia das Letras, 2006.

HOONAERT, Eduardo. A Igreja no Brasil - colônia [1550-1800]. São Paulo: Brasiliense, 1982.

LUIZETTO, Flávio. A Contra-Reforma. In. Reformas Religiosas - Lutero e Calvino. A Contra Reforma e os jesuítas - A crise da modernidade. $3^{\mathrm{a}}$ ed. São Paulo: Contexto, 1994.

MARRAMAO, Giacomo. Céu e Terra. Genealogia da secularização. São Paulo: Editora Unesp, 1997, p. 26-30, primeira edição italiana de 1994. Apud MONTEIRO, Rodrigo Bentes. As Reformas Religiosas na Europa Moderna - notas para um debate historiográfico. In. Varia Historia, Belo Horizonte, vol. 23, no 37: p. 130-150, Jan/Jun 2007. 
MOTT, Luis. Cotidiano e vivência religiosa: entre a capela e o calundu. In. SOUZA, Laura de Mello e. NOVAIS, F. (org) História da vida privada no Brasil: cotidiano e vida privada na América portuguesa. São Paulo: Companhia das Letras, 1997.

Alcântara,1994.

.Santos e Santas no Brasil Colonial. Fortaleza: Fundação Waldemar

Bertrand Russel, 1993.

Rosa Egipcíaca - Uma santa africana no Brasil. Rio de Janeiro:

OLIVEIRA, Rui A. Costa. Resquícios históricos da presença da Reforma no espaço lusófono durante o século XVI. Revista Lusófona de Ciência das Religiões - Ano, 2006/ $n^{\circ} 9 / 10-75-102$.

PIMENTEL, Helen Ulhôa. Universo Mágico Colonial. Feiticeiros e inquisidores nos dois primeiros séculos da colonização do Brasil. Brasília: 2005, p. 36.

PRIORI, Mary del. Ao sul do corpo: condição feminina, maternidades e mentalidades no Brasil Colônia. Rio de Janeiro: José Olympio; Brasília, DF: Edunb, 1993.

Paulo: Contexto, 1992.

Imagens da mulher. In. A mulher na história do Brasil. São

REVEL, Jacques. Os usos da civilidade. In. CHARTIER, Roger. (org); tradução Hildegard Feist. História da Vida Privada 3: da Renascença ao Século das Luzes. São Paulo: Companhia das Letras, 1991.

SILVA, Maria Beatriz Nizza da. Mulheres na Colônia: uma história a ser escrita. Revista Ler História. Ano, 2000/nº 39/ 59-79.

SOUZA, Laura de Melo e. Inferno Atlântico: Demonologia e colonização séculos XVI XVIII. São Paulo: Companhia das Letras, 1993.

Letras, 1986.

O Diabo e Terra de Santa Cruz. São Paulo: Companhia das

SOEIRO, Susan. The Social and Economic Role of the Convent: Women and Nuns in Colonial Bahia, 1677-1800. IN: Hispanic American Historical Review, vol. 54, $\mathrm{n}^{\circ} 2$, May 1974.

SPRENGER, James e KRAMER, Heinrich. Malleus Maleficarum, o martelo das feiticeiras. Rio de Janeiro: Rosa dos Tempos, 1991, Apud PIMENTEL, Helen Ulhôa. Universo Mágico Colonial. Feiticeiros e inquisidores nos dois primeiros séculos da colonização do Brasil. Brasília: UnB, 2005.

VAINFAS, Ronaldo. Trópico dos pecados: moral, sexualidade e inquisição no Brasil Colonial. Rio de Janeiro: Campus, 1989.

VASCONCELOS, Vânia Nara Pereira. Visões sobre as mulheres na sociedade ocidental. Revista Ártemis. Ano, 2005/ no 1/10.

ZORDAN, Gomes Barreto Menna Basso Paola. Bruxas: Figuras de poder. Revista Estudos Feministas. Ano, 2005/nº 002/vol. 13. Rio de Janeiro, Brasil. 